\title{
Human Capital Traps? \\ Enclave Effects Using Linked Employer-Household Data
}

\author{
Liliana D. Sousa \\ Center for Economic Studies, U.S. Census Bureau \\ May 30, 2013
}

The research in this paper was undertaken while the author was at Cornell University and the U.S. Census Bureau. Any opinions and conclusions expressed herein are those of the author and do not necessarily represent the views of the U.S. Census Bureau or Cornell University. All results have been reviewed to ensure that no confidential information is disclosed. This research uses data from the Census Bureau's Longitudinal Employer Household Dynamics Program, which was partially supported by the following National Science Foundation Grants SES-9978093, SES-0339191 and ITR-0427889; National Institute on Aging Grant AG018854; and grants from the Alfred P. Sloan Foundation. 


\begin{abstract}
This study uses linked employer-household data to measure the impact of immigrant social networks, as identified via neighborhood and workplace affiliation, on immigrant earnings. Though ethnic enclaves can provide economic opportunities through job creation and job matching, they can also stifle the assimilation process by limiting interactions between enclave members and non-members. I find that higher residential and workplace ethnic clustering among immigrants is consistently correlated with lower earnings. For immigrants with a high school education or less, these correlations are primarily due to negative self-selection. On the other hand, self-selection fails to explain the lower earnings associated with higher ethnic clustering for immigrants with post-secondary schooling. The evidence suggests that co-ethnic clustering has no discernible effect on the earnings of immigrants with lower education, but may be leading to human capital traps for immigrants who have more than a high school education.
\end{abstract}

JEL Classification: J15, J24, J31, J61

Key words: $\quad$ migration, ethnic enclaves, neighborhood effects, labor market assimilation

Corresponding author:

Liliana D. Sousa

Center for Economic Studies

U.S. Census Bureau

4600 Silver Hill Road

Washington, DC 20233

USA

E-mail: Liliana.D.Sousa@census.gov 
An important topic addressed by researchers studying immigration is the impact of ethnic enclaves on the economic assimilation of its members. Does the enclave serve as a "warm embrace" into the American economy or does it, on the other hand, serve to limit immigrant opportunities by reducing incentives and opportunities to assimilate? Immigrants who overly rely on the enclave economy can, in the words of Borjas (2000), become "the victims of a monopsony, a 'one-company' town." Previous studies have yielded mixed results: some have found a negative impact on wage growth (Borjas 2000; Pedace and Rohn 2008), others have found a positive effect (Wilson and Portes 1980; Edin, Fredricksson, Oslund 2003), while others report different effects for high and low education groups (Cutler, Glaeser, Vigdor 2008). These studies report divergent findings primarily due to how each measures "enclave behavior" and how each addresses self-selection into these communities. Though Wilson and Portes (1980), a foundational study in this area, define an enclave using ethnicity of the employer and coworkers within occupation/industry cells, most subsequent research has relied exclusively on residential information. This study contributes to this area of research by testing enclave effects using a linked household employer dataset that allows for the analysis of both residential and workplace ethnicity. Unlike most previous studies in this field, I am able to distinguish between the effects of residential clustering and workplace clustering, finding evidence that the two types of clustering operate differently on earnings.

Immigrants face extra obstacles in the labor market in addition to those faced by the native-born labor force. The devaluation or non-transferability of prior education and work experience are particularly salient concerns for recently arrived immigrants. Because of this, areas with high concentration of coethnics are attractive, particularly as initial location choices. Besides greater availability of ethnic goods, these communities provide access to more trade partners with shared language and culture, two characteristics that can substantially decrease transaction costs (Lazear 1999). In fact, Bayer, McMillan, and Rueben (2004) report that language skills explain almost $40 \%$ of Asian segregation and over $30 \%$ of Hispanic segregation in the San Francisco Bay Area. For immigrants with limited language skills and limited transferable education, ethnic networks may yield higher initial wages. The problem, however, may be that these same amenities may decrease the incentives to assimilate (i.e., acquire U.S.-specific human capital) while increasing the costs of assimilation. Learning a new language, for example, is faster and easier through immersion. In this way, residing in an enclave may lead to a human capital trap individuals are able to find work within the enclave but are not able to accrue the necessary U.S.-specific human capital for their careers to advance.

On the other hand, acquiring high levels of U.S.-specific human capital may prove inefficient for lowskill immigrants facing high assimilation costs and low expected returns from the labor market. Investing in country-specific human capital takes time, implying missed wages, while additional training and 
schooling can represent a steep financial investment. These costs will further vary by an individual's initial human capital stock: individuals with very low levels of education, for example, will require significantly more academic training to earn a high school equivalency diploma than those who already arrive in the U.S. with high school completed in their source country. Additionally, more schooling results in an improved ability to learn new skills (Rosenzweig 1995), suggesting that immigrants with low schooling will face higher effort costs. For these immigrants, investing into U.S.-specific human capital may not be the optimal choice even in the absence of ethnic communities. For them, the enclave provides important benefits, such as ethnic referral networks and access to ethnic goods, while minimizing everyday transaction costs.

Using linked household employer data, I explore how immigrant clustering in the workplace and in neighborhoods can impact wages and wage growth. In a descriptive longitudinal analysis, find consistently lower earnings and lower earnings growth for immigrants who reside or work with high concentrations of co-ethnics. After controlling for residential own-exposure rates, the longitudinal analysis indicates some positive returns to working with co-ethnics: immigrants in the $25^{\text {th }}$ through $75^{\text {th }}$ percentile of coworker own-exposure have higher earnings than those with lower or higher concentrations of co-ethnics. A second set of analyses relies on regressing either neighborhood or workplace concentration rates on earnings using only one year of earnings data. These regressions reveal strong negative relationships between both dimensions of ethnic enclaving and earnings, even after controlling for individual characteristics and country of birth. I find that sorting on unobservable traits may fully explain the lower earnings associated with higher residential and workplace concentration for immigrants with only a high school education or less. For immigrants with more than a high school education, however, sorting can only explain a small part of the earnings penalty associated with ethnic neighborhoods. I also find evidence of a large and significant earnings penalty of working with coethnics, potentially mitigated by self-selection. This may indicate that some immigrants with postsecondary education have unobservable qualities that make them relatively more productive in workplaces with more co-ethnics. Overall, I find clear evidence of negative enclave effects for immigrants with some post-secondary education, but very little evidence of a similar effect for lower education groups.

This study makes two contributions to the literature on enclave effects. It measures enclave effects along two dimensions of immigrant clustering: in the neighborhood and in the workplace. It then considers how ethnic clustering along these two dimensions affects highly educated immigrants differently from those without postsecondary education. These two dimensions of ethnic clustering represent important, yet potentially distinct, social networks: one is a source of ethnic goods and social interactions, while the 
other is more directly a source of economic opportunities and employment quality. The extent to which these two networks overlap is central to understanding how residential enclaves can lead to economic human capital traps. Immigrants who both work and live with co-ethnics may be too isolated from non co-ethnics, failing to acquire the necessary country-specific human capital to advance in the labor force. On the other hand, residing in an enclave might be the optimal strategy for those facing costly human capital investment choices. The evidence suggests that co-ethnic clustering has no discernible effect on the earnings of immigrants with lower education, but may be leading to human capital traps for immigrants who have more than a high school education.

\section{Literature Review}

Research on immigrant settlement patterns and enclaves has consistently documented the significant tendency of immigrants to choose locations within a host country with disproportionately large co-ethnic populations (for example, Bartel 1989 and Borjas 2000). This clustering behavior has led to large immigrant populations in several destination cities throughout the U.S., including the five metropolitan areas in this study. Within these large metropolitan cities, some immigrant communities have evolved into recognizable "ethnic enclaves" - neighborhoods with high concentrations of co-ethnic residents and businesses. Some well know examples include Little Havana in Miami, Chinatowns in Los Angeles and New York, and the Russian-born community in Brighton Beach, Brooklyn. Many other immigrants spill out into the suburbs in search of employment opportunities, better schooling, more affordable housing, and safer neighborhoods for their children. Recent immigration settlement patterns show higher immigrant settlement in the suburbs, even for immigrants with limited language skills who would, traditionally, settle into urban enclaves (Alba et al 1999).

Both economic and social reasons have been cited for ethnic clustering in host countries. Economies of scale in the production of ethnic goods, including marriage markets, food, and religious institutions, lead to the formation of ethnic communities. American immigration policy encourages family migration, leading to ethnic residential clustering as individuals choose to settle near relatives. Residential clustering of co-ethnics results in an increase in potential trade partners, due to a common language and cultural similarities, as discussed by Lazear (1999). Increasing the number of potential trade partners, ceteris paribus, increases economic opportunities for immigrants with limited ability to communicate or trade outside of the ethnic group. Ethnic communities can create employment and business opportunities for individuals by generating demand for ethnic labor, products, and services. McManus (1990), for example, finds a lower earnings penalty associated with not speaking English for workers within enclaves, while 
Borjas (1986) finds a positive proclivity for self-employment among immigrants who live in cities with more co-ethnics.

Unmeasured individual heterogeneity plays a significant role in labor market sorting and worker earnings, outweighing the effects of unmeasured firm heterogeneity (Abowd, Kramarz and Margolis 1999). The role of these unobserved characteristics is doubly important when we consider the role of social networks in job acquisition. Calvó-Armengol and Jackson (2004) show that the quality of one's social network, measured in terms of labor force attachment, can heavily influence one's own labor market outcomes and can directly affect the growth of inequality between different social groups. They illustrate the existence of positive externalities within referral networks whereby the employment of members of the network leads to higher employment levels throughout the network. Belonging to a lower quality network, thus, limits one's employment prospects. When applied to the context of ethnic enclaves, negative selfselection into ethnic social networks can lead to lower earnings for the members of these networks by limiting the number and quality of job referrals within the network.

Bayer, Ross and Topa (2008) find compelling evidence of referral networks operating between neighbors - specifically, they find that individuals are 33\% more likely to work with neighbors who live on the same block as they are to work with neighbors who live in the surrounding blocks. These referral networks result in higher earnings: a one standard deviation increase in potential referrals increases the earnings of men by between 2.0 and 3.7 percentage points. Thus, to the extent that residential location informs social networks, selection into ethnic neighborhoods can lead to selection into an ethnic job referral networks. While acquiring a job via a social network can yield higher than expected earnings, limiting one's social network to immigrants who negatively self-select might result in lower earnings. Andersson et al (2010) look at the proportion of coworkers who are immigrants for both natives and immigrants and find that limited English ability, industry of employment, and immigrant composition in the neighborhood account for $40 \%$ of total workplace immigrant composition. They also find that both residential clustering by country of origin and ethnic clustering in industries contribute heavily to coethnic own-exposure in the workplace - though these effects differ substantially between different countries of birth. Though they find evidence of sorting between workplaces by skill (workers with advanced degrees have larger shares of immigrant coworkers), they also document a significant correlation between residential co-ethnic exposure and co-ethnic workplace exposure, indicating the prevalence of neighborhood networks in the employment outcomes of immigrants.

Besides the lower transaction costs associated with working with co-ethnics who share a culture and language, another reason for co-ethnic clustering in the workplace might be discrimination in hiring. 
Using an audit study in Canada, Oreopoulos (2011) finds that individuals with English names were 39\% more likely to receive callbacks on their resumes than individuals with foreign-sounding names, ${ }^{1}$ even when they attended college and reported previous work experience in Canada. He finds that work experience outside of Canada substantially lowered call back rates, though employers did not penalize foreign schooling in conjunction with at least 4 years of Canadian work experience. Call back rates for foreign-sounding names with foreign education and foreign work experience (comparable in quality with Canadian counterparts) were $40 \%$ those of English names - indicating significant devaluation of education and work experience that occurs in countries deemed to be too different. ${ }^{2}$ This labor market discrimination may push immigrants with substantial education and work experience acquired overseas to work with co-ethnics or in ethnic-owned businesses, where their skills might be better evaluated.

Unmeasured individual characteristics lead both to non-random sorting into neighborhoods and nonrandom sorting into workplaces. Researchers have attempted several approaches to mitigate the effects of self-selection into enclaves. One approach has been to look at children or refugees, individuals who typically have their location in the host country chosen for them. Borjas (2002) finds that limiting the analysis to immigrants from source countries with high refugee rates did not significantly impact the measurement of the enclave effect on immigrant home ownership. Furthermore, Borjas (2000) finds that refugees are even more clustered than other immigrant groups: nearly $60 \%$ of the 1980 refugee population in the U.S. was clustered in 5 metropolitan areas compared to $49 \%$ of non-refugees. Similarly, using longitudinal data on detailed location, Edin, Fredriksson and Aslund (2003) find that $46 \%$ of refugees in Sweden had left their initial assigned municipality within 8 years and moved to an area with more immigrants. ${ }^{3}$ Due to this high internal migration of refugees, it is not clear that limiting the analysis to country of origin groups with relatively large refugee populations in the U.S. is a successful tool to address self-selection. Instead, Cutler, Glaeser and Vigdor (2007) limit the scope of their analysis to neighborhood effects on young adults and teenagers, arguing that their location is more likely to be exogenous since it was chosen by their parents. This age limitation severely limits the ability to study earnings and other labor market outcomes. Also, young immigrant adults in the labor force are a highly non-random group since college enrollment rates vary substantially between different immigrant groups.

The most prevalent approach used to address selection into areas of high co-ethnic concentration is to employ an instrumental variable analysis (for example, Altonji and Card 1991; Bertrand, Luttmer and

\footnotetext{
${ }^{1}$ Greek, Indian, Pakistani and Chinese names were used.

${ }^{2}$ The author notes no statistically significant penalty for employment that occurred in the U.K. compared to Canadian employment.

${ }^{3}$ Along the same lines, earlier research found significant return-migration to Miami by Cuban refugees who had been placed in other cities in the U.S. (Wilson and Portes 1980).
} 
Mullainathan 2000; Cutler, Glaeser and Vigdor 2008). While some researchers, such as Cutler, Glaeser and Vigdor (2008), instrument for neighborhood-level segregation indices using a demographic characteristic aggregated to a larger geography, others have used instruments relying solely on geographical aggregation, both contemporaneous and lagged. Altonji and Card (1991) use the proportion of immigrants from the previous decennial living in the city as an instrument for the immigrant population 10 years later in the same city, arguing that immigrant location is significantly influenced by the settlement patterns of previous waves independently of current labor market conditions in the area. Their instrument, thus, captures the migration that occurs into the given metropolitan area based on immigrant migration networks alone. Bertrand, Luttmer and Mullainathan (2000) use the contemporaneous proportion of co-ethnics ${ }^{4}$ at the city-level to instrument for neighborhood residential concentration in order to distinguish between sorting and network effects. They argue that, since costs are lower for within-city moves than for between-city moves, the effects of sorting will be larger at the neighborhood level than at the city level. Instead, they find evidence of stronger sorting into cities than into neighborhoods.

\section{Data $^{5}$}

This study draws its sample of analysis from immigrants residing in five of the largest immigrant destination urban areas ${ }^{6}$ in the U.S.: Los Angeles, New York, Chicago, Miami, Houston, and their suburbs. The sample is drawn from the confidential 2000 U.S. Census of Population and Housing, a onein-six household sample containing detailed residential and demographic data, including self-reported English language proficiency and the census block of residence. Adults aged 18 - 70 who report being in the labor force are matched to state Unemployment Insurance (UI) data provided through the Longitudinal Employer Household Dynamics (LEHD) program. ${ }^{7}$ Importantly, the LEHD data include place of birth, race, and a variable indicating Hispanic ethnicity for all workers in jobs covered by unemployment insurance (UI). These data allow the construction of employer-level ethnic and immigrant composition measures. One limitation of the LEHD data used in this project is that they do not provide earnings

\footnotetext{
${ }^{4}$ They look at language groups rather than country of origin groups.

${ }^{5}$ The sample used throughout this paper contains approximately 500,000 observations. Exact sample sizes are not being released for this draft to protect confidentiality.

${ }^{6}$ Consolidated Metropolitan Statistical Areas (CMSA) were used to identify these five urban areas. These are large urban areas that include several cities and their suburbs. These 5 CMSA's are composed of 26 Primary Statistical Areas (PMSA's), 15 of which comprise the New York City CMSA. A PMSA typical captures a city, borough, or suburban counties.

${ }^{7}$ For more information about the LEHD infrastructure files, please see Abowd et al (2006). Currently, UI data are available for all states except Massachusetts.
} 
information for federal employees and workers not covered by UI, such as those who are informally employed or paid "off the books" and the self-employed. ${ }^{8}$ Furthermore, matching of census data to the UI data is based primarily on social security numbers, hence any sampled individual without a valid social security number will not match between the census sample and the UI sample. ${ }^{9}$

The sample of analysis is all immigrants who reported being 18 through 70 years old in 2000, who were in the labor force, and who were residing in the five metropolitan areas listed above. The sample is furthermore limited to those who arrived in the U.S. as adults and who reported being in the labor force on the census and had valid UI records in 1999,2000 or $2001 .{ }^{10}$ Some basic demographic statistics for this sample are reported in Table 1. One fact to note is that the sample is evenly distributed between educational groups: half have a high school diploma or less and half have at least some post-secondary schooling. As found in other studies, immigrants are more likely than natives to have either very low levels of education or very high levels of education - over $17 \%$ have less than 9 years of schooling while over $12 \%$ have a professional or graduate degree. Almost $60 \%$ of the sample reports speaking English well or very well though only a quarter of the sample comes from countries in which English is an official language. ${ }^{11}$ The bottom of Table 2 also reports the average log of annual earnings (both for the entire sample and excluding the self-employed), age, and years since migration for the data universe as well as by education group. Table 4 reports the distribution of the country of birth of the data sample used in this analysis - showing that Mexican immigrants make up the largest group in the sample, though they represent a smaller share of the immigrant population in these five urban areas than nationally.

Co-ethnic exposure rates in the neighborhood and in the workplace are used to identify ethnic enclaves. ${ }^{12}$ Individual $i$ 's residential own-exposure rate is the proportion of adults in his census tract of residence, $k$, made up of co-ethnics, i.e. others who were born in the same country of origin, $j . C_{k}^{j}$, the residential ownexposure rate for group $j$ living in census tract $k$, is calculated as follows

\footnotetext{
${ }^{8}$ More recent vintages of the LEHD infrastructure files include federal employees. The self-employed universe is also currently being added.

${ }^{9}$ Preliminary analysis indicates that the match rates between the census and UI data for countries with high rates of undocumented immigration are in line with other country of birth groups, suggesting that few undocumented immigrants are dropped from the sample when linking to the LEHD data.

${ }^{10}$ Individuals who reported being self-employed and matched to the UI data were kept in the sample, though their self-employment status was controlled for in the regressions. All earnings are adjusted to year 2000 USD.

${ }^{11}$ English speaking country of birth is empirically defined as a country with English as an official language and with over $50 \%$ of all adult immigrants in the public-use 2000 Census speaking only English at home, as in Bleakley and Chin (2004).

${ }^{12}$ See Sousa (2011) for a detailed description of how these two measures were calculated and how they compare between different immigrant groups.
} 


$$
C_{k}^{j}=\frac{n_{j k}-1}{N_{k}-1}
$$

where $n_{j k}$ is the total number of adults in $k$ who were born in $j$, and $N_{k}$ is the total population in $k{ }^{13}$

Similarly, $C_{w}^{j}$ is the workplace own-exposure rate, calculated as above where $w$ is the individual's workplace. ${ }^{14}$ Workplace is defined differently for three groups: 1) it is the dominant employer in the year 2000 if the establishment had at least 6 employees, 2) it is the pseudo-firm made up of all workplaces in the same census block for individuals who had fewer than 5 coworkers, and 3) for self-employed individuals, workplace own-exposure is calculated over all other self-employed individuals in the same PMSA and the same collapsed industry group. Andersson et al (2010) show that the mechanics of calculating coworker shares at the firm-level leads to lower variance in coworker shares for very small firms. Because of this, I measure the ethnic composition in pseudo-firms instead, a strategy employed successfully by Bayer, Ross and Topa (2008). The self-employed are included in this analysis for two reasons: selection and outside earnings. Selection into self-employment can vary dramatically by country of birth groups, hence their exclusion from analyses of labor outcome among immigrants can result in serious distortions. Also, a large fraction of the self-employed report significant proportions of their income earned through employment rather than their own business, suggesting a strong attachment to the formal labor market even for those who report being self-employed. All regressions are run with and without the self-employed. The results are very similar across both samples for all specifications.

Table 1 reports the distribution of these three workplace types: $86.1 \%$ of the sample works in establishments with 6 or more employees, $7.1 \%$ are self-employed, and $6.8 \%$ of the sample works in establishments with 5 or less employees. Table 3 reports the average workplace co-ethnic exposure rate by type of workplace for the data universe as well as for each educational group. Workers in establishments with more than 5 employees have a higher average level of co-ethnic exposure at the workplace than the other two employer types. This is, at least in part, due to the methodology used to calculate these exposure rates. To control for these methodological differences, control variables for workplace type are included in all regressions.

The first two rows of Table 2 report the average residential co-ethnic exposure rate, $C_{k}^{j}$, and the average workplace co-ethnic exposure rate, $C_{w}^{j}$, for the full sample and for high and low education groups.

\footnotetext{
${ }^{13}$ This exposure rate was also used by Bayer, McMillan and Rueben (2004) and Andersson et al (2010).

${ }^{14}$ Individuals who worked in multi-unit firms were assigned an establishment using the Unit-to-Worker Impute (Abowd et al 2006). Regressions were run using both firm-level and establishment-level concentration rates. The results were very similar. All reported results are from the establishment-level measure.
} 
Workplace co-ethnic exposure rates are slightly higher than residential co-ethnic exposure rates for each of the three samples. On average, immigrants without post-secondary education both live and work with double the proportion of co-ethnics ( $16.0 \%$ and $16.7 \%$ respectively) as immigrants with more than a high school diploma ( $7.5 \%$ and $8.7 \%$ respectively). Overall, the average immigrant in this sample of five large cities with significant immigrant populations lived in neighborhoods with about $11.8 \%$ co-ethnics and worked in workplaces with about $12.7 \%$ co-ethnics. Additionally, Table 2 reports the co-ethnic exposure rates at the PMSA level in the years 1990 and 2000. These are calculated as the proportion of the PMSA in-sample population (including the native-born) that belongs to each individual's ethnic group. As expected, these values are significantly lower than the neighborhood and workplace co-ethnic exposure rates, with an average of $3.5 \%$ in 1990 and $4.2 \%$ in 2000. Immigrants without post-secondary education have PMSA-level co-ethnic exposure rates about twice the size of immigrants with post-secondary education. That is, immigrants with lower educational attainment belong to larger immigrant groups and/or seek out cities with higher co-ethnic concentration.

\section{Earnings Growth Analysis}

This descriptive analysis examines earnings trends for native-born workers and immigrants by ownexposure rates using longitudinal UI earnings from 1995 through $2008 .{ }^{15}$ Figure 1 shows a consistent earnings gap of about $\$ 10,000$ between the earnings of the U.S.-born and immigrants for the 13 years plotted. Figure 2 shows that this earnings gap is caused primarily by the lack of earnings' growth in immigrant earnings between the ages of 30 and 60. This lack of earnings growth during prime earning years is partially due to compositional factors: as immigrants arrive in the U.S. at older ages and enter the labor market with less U.S.-specific human capital, they decrease the average earnings for immigrants at that age group. Additionally, different waves of immigrants possess different skill compositions. These cohort effects are well-established in the literature on immigrant earnings (Borjas 1985). Figure 3 illustrates this effect by plotting earnings by age separately for six different arrival cohorts: 1) 1968 and earlier, 2) between 1969 and 1975, 3) between 1976 and 1982,4) between 1983 and 1987, 5) between 1987 and 1994, 6) 1995 and later. These cohorts are designed to correspond to two important immigration policy changes in the U.S.: 1) the immigration act of 1965 (which went into effect in 1968) eased restrictions on the legal immigration of non-European immigrants, and 2) the Immigration Reform and

\footnotetext{
${ }^{15}$ Earnings are the total earnings reported by all employers to state UI programs. To calculate the means in the following figures, annual earnings of less than $\$ 1,000$ or more than $\$ 1$ million, and those for individuals who were less than 18 years old were excluded. These restrictions trim annual observations by less than $8 \%$. Less than $0.01 \%$ of the remaining observations were dropped due to potential quality concerns regarding the social security numbers used for the linking between the two primary data sources.
} 
Control Act of 1986 (IRCA), which granted amnesty for undocumented immigrants who had arrived prior to 1992 while instituting penalties on employers who hire undocumented labor. As a result of these policy changes, the country of origin groups in these cohorts vary substantially: the first is made up primarily of Western European immigrants while the most recent cohorts are composed of large majorities from Latin America. However, even for cohorts that had been in the U.S. for over 20 years as of 1995, earnings are still notably lower than for the native population.

The native-immigrant wage gap can be attributed to various factors - but the one that is explored in this study is the role of enclaving, residentially and at the workplace. In order to illustrate earnings growth by co-ethnic exposure rates, both residential and workplace own-exposures are collapsed into quartiles and average annual earnings for each group are plotted in Figure $4 .{ }^{16}$ Immigrants living in the least co-ethnic neighborhoods, the lowest quartile of residential own-exposure, ${ }^{17}$ report the highest earnings - by 2008 their average earnings were over $\$ 54,000$, slightly higher than average earnings for the overall U.S.-born population shown in Figure 1. On the other hand, the quartile belonging to those who live in neighborhoods with the largest shares of co-ethnics had exceptionally low earnings, just barely surpassing $\$ 28,000$ in 2007. Also notable is the lower earnings growth of immigrants living in high residential ownexposure communities. Whereas average earnings grew by $39 \%$ over the 13 years of analysis for the three quartiles with lower levels of residential own-exposure, average earnings only grew by $34 \%$ for the highest quartile. Note that all four quartiles of residential own-exposure report higher earnings growth than the $31 \%$ seen among the U.S.-born sample, evidence of gradual economic assimilation.

This relationship between residential own-exposure quartile and earnings survives the inclusion of demographic factors related to earnings. Table 5 shows that even with the inclusion of controls for employer and personal characteristics, including place of birth and PMSA of residence, immigrants in the first quartile of residential own-exposure earn significantly more than immigrants in any other quartile. Since the dependent variable is log of earnings, the OLS coefficients indicate that immigrants in quartiles 3 and 4 earn between 10 and $13 \%$ less than similar immigrants in the first quartile. Immigrants in quartile 2 are more similar to those in quartile 1 , suffering a relative earnings decrease of only $3.5 \%{ }^{18}$

Though the relationship between earnings and quartile of residence is consistently negative - individuals in higher quartiles of own-exposure have lower earnings - the relationship between earnings and

\footnotetext{
${ }^{16}$ Quartiles are calculated based on 2000 residence and workplace so the data plotted for each year is composed of the same individuals (excluding annual observations with no reported income or that occurred before the individual turned 18). Standard errors range from a high of 400 for the first quartile to a low of 113 for the fourth quartile. Note that these trends are robust to the exclusion of the self-employed.

${ }^{17}$ Quartile cut off values are not reported since they have not been released by the U.S. Census Bureau.

${ }^{18}$ Similar regressions including the self-employed yield smaller coefficients, but the same patterns.
} 
workplace own-exposure is not as consistent. The first two quartiles of workplace own-exposure result in overlapping earnings trends. The other two quartiles, however, mirror the high quartiles of residential own-exposure by exhibiting lower earnings. Three of the workplace quartiles have earnings growth rates of $37-38 \%$; the second quartile, however, shows a higher earnings growth rate of $45 \%$ over the 13 years plotted. Table 5 shows that immigrants in the second quartile of workplace own-exposure earn 5.8\% more than immigrants in the first quartile when the regression controls are added. Immigrants in the third quartile earn 3.8\% more than those in the first quartile while immigrants in the fourth quartile might earn less (though this coefficient is not statistically significant). These results are very similar when the selfemployed are included.

As suggested by the earnings trends in Figure 4, ethnic segregation operates differently in the neighborhood and in the workplace. While higher concentrations of co-ethnic neighbors implies lower earnings, selecting into firms with some co-ethnic workers may result in higher earnings than either working with almost no co-ethnics or with mostly co-ethnics. To further explore the role of ethnic ownexposure in the labor market and residential areas, I interact the two own-exposure rates to create a twodimensional measure of enclave proclivity. Table 6 details the distribution of the interaction of these two measures. The two largest groups are the groups at the extremes: immigrants who do not live or work with large proportions of co-ethnics, and immigrants who both live and work in high co-ethnic areas. ${ }^{19}$ Figure 5 focuses on the first and fourth quartiles of residential own-exposure and dissects each by the quartile of workplace own-exposure. It shows a considerable earnings gap between immigrants who neither live nor work with high proportions of co-ethnics and immigrants who both live and work in high co-ethnic areas and workplaces. Regressing log of earnings on the interacted own-exposure quartiles confirms that immigrants in the quartile of lowest residential own-exposure who are in the middle quartiles of workplace own-exposure earn more than similar immigrants who work with a smaller concentration of co-ethnics. Another interesting finding on Table 7 is that this pattern holds for all residential own-exposure quartiles: within each quartile, immigrants who were in either the first or last workplace own-concentration quartiles earned less than immigrants in the middle quartiles. Working in workplaces with moderate proportions of co-ethnics is associated with higher earnings, controlling for quartile of neighborhood co-ethnic exposure. The results are qualitatively similar when the self-employed are included, though the coefficients tend to be smaller.

This first pass at the data confirms that earnings are lower among immigrants who live or work in high co-ethnic areas or firms. However, it also indicates that the relationship between workplace co-ethnic

\footnotetext{
${ }^{19}$ For a more detailed analysis of the interaction between residential and workplace own-exposure rates among this sample, see Sousa (2011).
} 
exposure and earnings is not monotonic - instead, it appears that working in firms with moderate levels of co-ethnic exposure may lead to higher earnings than working in firms with exceptionally low levels of coethnics or those with exceptionally high levels of co-ethnics.

\section{Regression Models and Analysis}

The figures and regressions based on quartile of own-exposure reported above, in addition to the annual earnings figures, show that workplace and residential networks do not have the same relationship with earnings. Instead, some degree of co-ethnic workplace exposure is correlated with higher earnings implying that residential and workplace ethnic networks are different and operate differently with respect to labor market outcomes. I investigate these mechanisms below by running regressions on earnings using own-exposure rates instead of quartiles as the primary explanatory variables.

\subsection{Estimating Human Capital Accumulation}

Economic research on immigrants relies heavily on cohort analysis (Borjas 1985) and/or the inclusion of a measure of years since migration to estimate the effects of country-specific human capital accumulation on earnings. Since data limitations prevent this project from utilizing cohort analysis, I cannot directly estimate rates of human capital accumulation such as education or English skills acquired after immigration. Ideal data would include time variant measures of education and English-skills to capture human capital accumulation but data on education and English-skills are limited to one point in time: the 2000 Census. Some identification from these data is still possible: for example, we know who did not learn English and we know who emigrated from a country where English is not spoken but now reports speaking English. As a result, I control for years since migration and two basic estimates of U.S.-specific human capital accumulation: minimum education completed in the U.S. and whether English is an official language in the country of birth.

The decision to learn English is motivated by a desire to increase the number of potential trade partners. Lazear (1999) argues that "those who learn English after coming to the United States perform the same calculation, but do so at a later stage" as those who learned English prior to immigration. In order to capture this choice to learn, the analyses below include both the self-reported language skills of the immigrant in the year 2000 and an indicator variable equal to 1 if English is an official language in the country of birth (as determined in Bleakley and Chin 2004). 
Including immigrants who arrive as children in models of human capital accumulation complicates the interpretation of the value of education (since this education is primarily received in the U.S.) and the value of years since migration (since the effect of time in the U.S. may be different during childhood). Some previous research has relied on samples limited to immigrants who arrived after age 25 since most individuals have completed their education by this age. However, limiting the sample to those who immigrate after their education has been completed can result in biased samples if the process by which individuals select into immigration and into higher education vary by country and by age. Indeed, in countries with low educational attainment and low costs of immigration, such as Mexico, Guatemala, and El Salvador, individuals who elect to emigrate in early adulthood may have different employment expectations than those who choose to immigrate after the age of 25 . Table 8 shows that $34-38 \%$ of immigrants from these three countries immigrated between the ages of 18 and 25, far higher than the average of about $27 \%$ for other country of birth groups. If those who immigrate after age 25 differ from those who emigrate earlier in unobservable characteristics, then limiting the sample in this manner will yield biased and unrepresentative results, with this bias being more significant for groups with high rates of emigration in early adulthood. Instead, in this paper, I limit the universe to immigrants who first arrive in the U.S. at the age of 18 or later, regardless of when they enter the U.S. labor market.

With the inclusion of younger immigrants, I also address where education was completed. Since many individuals do not complete their formal education until their mid-20s, I create a new variable measuring estimated education in the U.S. using a similar approach as language above. Specifically, given the age at arrival in the U.S. and the total education completed, a measure of maximum source country education can be developed. For example, an individual who emigrates at age 18 but reports having a college education is assumed to have a maximum source country education limited to high school and a U.S. college education. By construction, education levels of high school diploma or less are assumed to have been completed prior to immigration since the sample is limited to those who immigrated at age 18 or later. For immigrants with more than a high school diploma, age at arrival directly determines the value of maximum education completed in the U.S. - this approach fails to identify individuals who continue their education as non-traditional students later in life. Any resulting bias in the estimate of U.S. human capital accumulation will be negative since this measure is purposely conservative in estimating education in the U.S.

\subsection{OLS Regression Analysis}

Earnings are a function of standard human capital and demographic characteristics (age, gender, race, ethnicity, marital status, city of residence, and education), plus immigrant-specific traits (English ability, 
years since migration, and country of birth). A full set of country or region of birth and area of residence indicators are included to address some of the systematic differences between country of birth groups (including the differing selection processes by which immigrants select into immigration) and to control for differences in earnings and employment opportunities in the five urban areas included in this study. Additionally, the log of the firm size and indicators for whether the person reported being self-employed in 2000 or worked in an establishment with less than 6 people $\left(E T_{i}\right)$ are included. $C_{t}^{j}$ is the share of coethnics either in the neighborhood (when $t=k$ ) or in the workplace (when $t=w$ ). Hence, the effect of co-ethnic concentration on the log of earnings is $\beta_{7}$.

$$
\begin{aligned}
& \ln \left(y_{i}\right)=X_{i} \beta_{1}+\beta_{2} y s m_{i}+\beta_{3} e_{i}+\beta_{5} \text { eng }_{i}+\beta_{6} \text { POBeng }_{i}+\beta_{7} C_{t}^{j}+P O B_{j}+C M S A_{k}+e_{i} \\
& \text { where } X_{i}=\left[\text { age }_{i}, \text { age }_{i}^{2}, \text { male }_{i}, \text { race }_{i}, \text { Hisp }_{i}, \text { married }_{i}, \text { size } E T_{i}\right] \\
& t \in\{k, w\}
\end{aligned}
$$

These regressions yield consistently negative and significant coefficients for the residential and workplace own-exposures as reported in Table 9. This is the case even after controlling for education and other individual human capital measures and taking certain precautions against selection by including a vector of country of birth dummy variables and a vector of CMSA of residence dummy variables. The four columns on the right report the results by education group (more than a high school diploma and high school diploma or less). For each specification, the standard human capital results emerge: age ${ }^{20}$ and years since migration (YSM) are both concave and speaking English and having more formal schooling are both associated with higher earnings.

Speaking English well or very well is associated with a 15\% increase in reported earnings for immigrants born in countries where English is not an official language. This premium is slightly higher for immigrants with more than a high school education (17\% versus $13 \%)$. The earnings premium associated with emigrating from a country where English is one of the official languages is about 20\%; that is, all else equal, an immigrant who does not speak English but is from an English-speaking country (such as a French Canadian) will earn $20 \%$ more than a similar immigrant from a country where English is not an official language (such as France). This suggests the presence of other benefits of being born in an English-speaking country in transitioning into the American labor market - perhaps similarity in social or labor force institutions.

\footnotetext{
${ }^{20}$ Age and its square are not included in this table of results. These coefficients can be obtained from the author upon request.
} 
The returns to formal schooling are consistent with previous research - the returns increase exponentially as schooling increases. The increase from an $8^{\text {th }}$ grade education to a $10^{\text {th }}$ grade education implies an increase of only $5 \%$ in earnings, whereas an increase from an $8^{\text {th }}$ grade education to a high school diploma is a $10 \%$ increase, to a college degree is a $58 \%$ increase, and to a graduate degree is an $83 \%$ increase in earnings. Attending college or graduate school in the U.S. yields an earnings premium of about $6 \%$ compared to arriving with a degree from abroad. As discussed above, because this measure of U.S. education is purposely conservative, it underestimates the impact on earnings of receiving a U.S. college or graduate degree.

The final two coefficients listed in Table 9 are control variables for whether the individual works in an establishment with 5 or fewer coworkers and the log of firm size (measured as the number of employees that the firm reported in that year across all of its establishments). The inclusion of the small workplace indicator is to control for the differences in methodology in calculating workplace own-exposure. Immigrants working in these small workplaces report earnings roughly $33 \%$ lower than those who work in larger establishments. In combination with the log of firm size, this suggests a very high earnings penalty for working in small firms.

All six regressions reported in Table 9 find that increased rates of own-exposure (both in the neighborhood and at the workplace) have a negative impact on earnings. The coefficients on workplace exposure rate report a nearly identical effect on earnings for both educational attainment groups: moving from a firm with $0 \%$ co-ethnics to one with $100 \%$ co-ethnics implies earnings that are between 17 and $18 \%$ lower. ${ }^{21}$ As shown in Table 2, immigrants with more than a high school degree work in firms with lower co-ethnic exposure rates. At the mean workplace co-ethnic exposure rates for each group, an immigrant with some post-secondary education earns about $1.5 \%$ less than he would in a workplace with no co-ethnics while an immigrant with a high school education or less earns $3 \%$ less than if he worked with no co-ethnics. On the other hand, the effects for residential co-ethnic exposure differ dramatically between educational groups. While the average effect of going from a neighborhood with no co-ethnics to one composed entirely of co-ethnics is a $25 \%$ decrease in reported earnings, it is a $46 \%$ decrease for those with more than a high school education and only a $14 \%$ decrease for those with less education. Again, using the average residential co-ethnic exposure rates reported in Table 2, this implies an average decrease in earnings of about $3 \%$ for high education immigrants and $2 \%$ for those with less education. These results support the hypothesis that highly educated immigrants face significantly larger opportunity

\footnotetext{
${ }^{21}$ Relative to previous versions of this paper, the inclusion of the log of firm size greatly reduced the estimated effects of working with more co-ethics while having minimal impact on the effects of residential concentration.
} 
costs to living in an ethnic enclave, but fail to support a similar hypothesis for workplace segregation. Table 10 shows that the inclusion of the self-employed does not greatly affect the coefficients of interest.

\subsection{Instrumental Variable Analysis}

Previous research has struggled with the self-selection problems inherent in looking at residential choice patterns. Immigrants do not sort randomly into ethnic enclaves; rather, observed and unobserved traits influence an individual's residential choice. Sousa (2011) shows that observables explain half of the individual variation in residential own-exposure and a quarter of workplace own-exposure. Not speaking English and the individual's country of birth are two of the most important factors. Problems of selection arise if an unobserved trait, such as ability or proclivity to assimilate, influences both residential choice and earnings outcomes. Specifically, let $A_{i}$ denote an unobserved personal characteristic that decreases the willingness or ability to assimilate and, independently, decreases earnings. That is

$$
\begin{aligned}
& \frac{\partial\left[C_{i, t}^{j}\left(A_{i}\right)\right]}{\partial A_{i}}>0 \\
& \frac{\partial\left[y_{i}\left(A_{i}\right)\right]}{\partial A_{i}}<0
\end{aligned}
$$

As is readily apparent, if $A_{i}$ exists, regression specification (I) yields a biased estimate of $\beta_{7}$. To address this endogeneity, this study combines the instrumental variable strategies employed by Altonji and Card (1991) and Bertrand, Luttmer and Mullainathan (2000). Specifically, the omitted instrument for $C_{i, t}^{j}$ is the 1990 PMSA-level of residential ethnic concentration.

It is a necessary condition for successful instrumentation that the omitted variable only affect the outcome of interest (wages) through the variable being instrumented (co-ethnic concentration). The proportion of the PMSA population that is co-ethnic is an important predictor of both residential and workplace ownexposure rates since belonging to a larger group increases the risk of having more co-ethnic coworkers or neighbors even through random sorting. It is possible that the size of the ethnic community in an urban area would influence the wages received by co-ethnics. As shown in Blanchard and Katz (1992), local labor markets adjust to labor supply shocks within a decade. Using the 1990 co-ethnic share rather than the 2000 co-ethnic share allows enough time for the local labor market to adjust to specific immigrant inflows and outflows.

Another quality necessary in a good instrument is that it not be endogeneously affected by $A_{i}$. As early as Bartel (1989), research has shown that the settlement patterns of earlier co-ethnics play a significant role 
in determining where individuals choose to settle. We might still suspect that immigrants less likely to assimilate will be more predisposed to following the migration decisions of previous co-ethnics. Because of this, the sample itself is limited to the five urban areas in the U.S. with the highest immigrant population. That is, the sample has already been limited to individuals who are drawn to areas of high coethnic population. Furthermore, the ten-year lag is an imperfect predictor of where current enclaving is occurring. For example, many immigrant groups have gradually moved from the inner cities to the suburbs, resulting in a change in PMSA-level ethnic concentrations.

\subsection{Instrumental Variable Regression Results}

Table 11 reports results for the six regressions reported in Table 9: one for each co-ethnic exposure rate in the neighborhood and at work using the entire sample, and then by educational attainment. Two concerns arise in the use of an instrumental variable approach: instrument relevance and instrument exogeneity. While exogeneity cannot be empirically verified, instrument relevance is easily established by looking at the results from the first stage regression. The high F-statistics associated with each of the first stage regressions reported in Table 11 show that, for all specifications, the instruments in these models are highly predictive of the endogenous variable being instrumented (Stock, Wright and Yogo 2002). The regression table also reports the $t$-statistic of the excluded variable, showing that it is a consistently important predictor of the endogenous variable being instrumented.

The results using the instrumented residential and workplace exposure rates support the conclusion that self-selection plays a significant role in explaining the negative impact on earnings that was found using the OLS regressions, especially for immigrants with low educational attainment. For the full sample, controlling for self-selection decreases the negative impact of residential clustering by over a third while the estimated effect associated with higher workplace co-ethnic exposure increases by about the same magnitude. Once the sample is stratified by educational attainment, however, the results highlight differences in sorting for low and high education immigrants.

For immigrants with a high school education or less, instrumenting for co-ethnic exposure rates yield smaller own-exposure effects than the OLS specification. Neither of the coefficients on either type of coethnic exposure rates is statistically different from 0 , allowing for the possibility that negative selfselection fully explains the negative effects of ethnic clustering for immigrants with less education. The expected loss in earnings of going from a workplace with no co-ethnics to one with just co-ethnics drops from $14 \%$ in the OLS specification to $3 \%$ in the IV specification for immigrants with a high school education or less. At the same time, the decrease in predicted earnings from moving from a neighborhood with no co-ethnics to one fully composed of co-ethnics drops from $18 \%$ to $5 \%$. 
However, for those with more than a high school education, the 1990 instrument results in statistically significant negative effects for both living and working with more co-ethnics. While correcting for sorting mitigates the average earnings penalty of residential co-ethnic exposure from $3.5 \%$ to $2.7 \%$, it more than triples the average earnings penalty associated with working in firms with higher concentrations of coethnic employees to $5.2 \%$ from $1.5 \% .^{22}$ This suggests that both living and working with more co-ethnics, all else equal, leads to significantly lower earnings for immigrants with more than a high school education.

Comparing the coefficients reported in Table 12 to those in Table 9, we see that correcting for sorting on unobservables decreased the measured effect of enclaving in five out of the six regressions. The interpretation for these drops in the coefficients is that negative self-selection explains at least some of the negative earnings associated with enclaving. However, in the regression that looks at workplace enclaving for immigrants with more than a high school degree, the IV regression yields a larger negative effect of enclaving. That is, there is a stronger negative effect of enclaving after addressing sorting. One possible interpretation is that there is some positive self-selection into high co-ethnic workplaces. These workplaces pay less, all else equal, but the workers selecting into them are more productive. Another interpretation is that the individuals who select into enclave employment are more productive in these workplaces than they would be outside of enclaved workplaces. In this way, enclave employment is a second best option: the highest income is from working with few co-ethnics but, given an individual's unobservable characteristics, he increases his income by working in a high co-ethnic workplace.

These results suggest different employment and human capital accumulation mechanisms within the neighborhood and within the workplace for immigrants with more than a high school education. Residing in areas of relatively high co-ethnic exposure may decrease earnings by limiting social interactions with individuals who are not co-ethnics, thus decreasing the accumulation of country-specific human capital. In general, immigrant clustering in the workplace decreases the earnings of immigrants with more than a high school education. However, immigrants with unobservable traits that are less valuable in the nonethnic labor market, perhaps an inability to assimilate leading to lower productivity levels in integrated firms, are selecting into firms with higher co-ethnic concentrations where they are more productive.

\footnotetext{
${ }^{22}$ The estimated wage penalties reported here are measured at the average residential co-ethnic exposure for immigrants with more than a college diploma, as reported in Table 2. Similarly, the average workplace co-ethnic exposure rate for immigrants with more than a high school education is used to estimate the wage penalties in the workplace.
} 


\subsection{Occupational Clustering}

Occupational choice was excluded from the above regressions due to the likelihood that it is endogenous: individuals who choose to enclave are more likely to choose occupations facilitated by the enclave - or, alternatively, choose the enclave based on their chosen occupation. However, due to the role of occupational choice in determining earnings, regressions were run controlling for seven occupational categories. Table 12 details the five largest of these and what proportion of workers in each workplace quartile group fall into each. ${ }^{23}$ Immigrants in the lowest workplace quartiles tend to be in professional and office occupations, while immigrants in the highest workplace quartiles are in services and production occupations.

Table 13 reports the coefficients from both the OLS and IV regressions after controls for occupational choice are included. Though the story that emerges is the same, some of the coefficients vary substantially. This is particularly the case for the OLS coefficients for immigrants with more than a high school education. Comparing these coefficients to those in Table 9 reveals a significant drop in the coefficient on the residential own-exposure rate. This suggests that a significant portion of the earnings penalty for highly educated immigrants attributable to residential clustering is explained by the occupational choices of these individuals. Comparing the IV results to those in Table 11 shows that occupational choice decreases the earnings penalties of highly educated immigrants after controlling for self-selection. In spite of these changes, the self-selection story remains unchanged, supporting the hypothesis that, even controlling for occupational choice, immigrants with post-secondary schooling who self-select into high co-ethnic neighborhoods or workplaces face an earnings penalty.

\subsection{Neighborhood Labor Networks}

Previous research has found neighborhood-level labor networks independent of ethnicity (Bayer, Ross and Topa 2008; Andersson et al 2010). If immigrants are more likely to cluster in neighborhoods with more co-ethnics, neighborhood-level labor networks would yield more co-ethnic coworkers even absent a preference for co-ethnic coworkers. It would mean, then, that the workplace own-exposure rates are largely determined by residential own-exposure rates, implying that the effects of workplace ownexposure rates are in fact being driven by residential choice.

To address this concern, I calculate the following measure of neighborhood labor market network

$$
C_{f k}=\frac{W_{f k}-1}{W_{f}-1}
$$

\footnotetext{
${ }^{23}$ Two occupational groups are excluded from this table due to small cell size. They are included in the regressions.
} 
where $W_{f}$ is the set of all individuals who work at the same establishment (or block of employment for smaller employers), and $W_{f k}$ is the set of all coworkers who also reside in the same neighborhood as the individual. Hence, $C_{f k}$ is the share of coworkers who are also neighbors, independent of country of birth. This variable is then included in the OLS and IV regressions to control for the neighborhood labor market network.

Table 14 reports the coefficients on residential and workplace own-exposure for the OLS and IV regressions for the full sample, and for the sample stratified by education. Comparing these results to those on Tables 9 and 11 supports previous research showing important neighborhood-level labor networks. For each sample, the inclusion of the ratio of coworkers who are also neighbors slightly increases the magnitude of the OLS coefficient on residential own-exposure while slightly decreasing the coefficient on workplace own-exposure. However, the IV results offer more evidence of negative selfselection and human capital traps for immigrants with a postsecondary education who choose to enclave. As before, addressing self-selection resulted in a smaller earnings penalty associated with residential ownexposure but a much larger earnings penalty associated with workplace segregation. The earnings penalties associated with higher co-ethnic own-exposure rates for immigrants with more than a high school education grew by 4-6 percentage points after controlling for the proportion of coworkers that are also neighbors. This further supports the hypothesis of a negative enclave effect for immigrants with some post-secondary education.

\section{Conclusion}

Immigrants who live and work in high co-ethnic areas and firms earn less. But, would these immigrants earn more if they did not enclave? The counterfactual, of course, is not observed. However, the instrumental variable estimates addressing self-selection into high co-ethnic neighborhoods and high coethnic employers suggest that the findings of negative enclave effects are partially due to negative selection. Specifically, negative selection into co-ethnic neighborhoods and workplaces explains almost the entirety of the earnings penalties associated with enclaving for immigrants with a high school education or less. On the other hand, even after addressing sorting on unobservables, earnings penalties associated with both types of enclaving remain large and significant for immigrants with more than a high school education. For these immigrants, lower earnings attributed to residential ethnic exposure are only partially explained by self-selection - the remainder may well be due to limited referral networks and human capital traps. For the average immigrant with more than a high school education in the sample of 
analysis, residential and workplace enclaving are responsible for earnings penalties of $2.7 \%$ and $5.2 \%$, respectively. At the same time, I find evidence that the negative self-selection into high co-ethnic employers may be a second best strategy; these workers are choosing firms where they are more productive, or more highly valued, perhaps due to lower transaction costs as argued in Lazear (1999). These results are robust to the inclusion of variables controlling for occupational choice and neighborhood-level labor market networks.

There is no question that negative self-selection is leading to higher co-ethnic concentrations in ethnic neighborhoods and workplaces. Relying on earlier work on social networks, this negative selection can lead to lower earnings and less employment opportunities since the quality of the network will lead to externalities for its members (Calvó-Armengol and Jackson 2004). However, given the limited employment opportunities for immigrants with low educational attainment or limited English skills, this negative self-selection does not seem to yield lower earnings than would otherwise be expected. For immigrants with some postsecondary education, however, I find evidence of human capital traps. For these immigrants, working or living with more co-ethnics results in lower earnings. The evidence suggests that enclaves are not creating a "warm embrace" for immigrants with low levels of education, though they are not necessarily hurting these immigrants either. On the other hand, immigrants with more than a high school education face earnings penalties due to both types of ethnic clustering, supporting the existence of human capital traps. 


\section{References}

Abowd, John M., Francis Kramarz and David Margolis. 1999. High Wage Workers and High Wage Firms. Econometrica 67:2.

Abowd, John M., Bryce E. Stephens, Lars Vilhuber, Fredrik Andersson, Kevin L. McKinney, Marc Roemer, and Simon Woodcock. 2006. The LEHD Infrastructure Files and the Creation of the Quarterly Workforce Indicators. U.S. Census Bureau, Center for Economic Studies Technical Paper Series, TP 2006-01.

Alba, Richard D., John R. Logan, Brian J. Stults, Gilbert Marzan, and Wenquan Zhang. 1999.

Immigrant Groups in the Suburbs: A Reexamination of Suburbanization and Spatial Assimilation. American Sociological Review 64:3.

Altonji, Joseph G. and David Card. 1991. The Effects of Immigration on the Labor Market Outcomes of Less-Skilled Natives. Immigration, Trade and Labor, ed John M. Abowd and Richard B. Freedman. Chicago, University of Chicago Press.

Andersson, Fredrik, Monica Garcia-Perez, John Haltiwanger, Kristin McCue, and Seth Sanders. 2010. Workplace Concentration of Immigrants. U.S. Census Bureau, Center for Economic Studies Working Papers CES 10-39.

Bayer, Patrick, Robert McMillan, and Kim S. Rueben. 2004. What Drives Racial Segregation? New Evidence Using Census Microdata. Journal of Urban Economics 56.

Bayer, Patrick, Stephen Ross, and Giorgio Topa. 2008. Place of Work and Place of Residence: Informal Hiring Networks and Labor Market Outcomes. Journal of Political Economy 116:6.

Bertrand, Marianne, Erzo Luttmer, and Sendhil Mullainathan. 2000. Network Effects and Welfare Cultures. The Quarterly Journal of Economics 115:3.

Blanchard, Olivier Jean and Lawrence F. Katz. Regional Evolutions. Brookings Papers on Economic Activity 1992:1.

Bleakley, Hoyt and Aimee Chin. 2004. Language Skills and Earnings: Evidence from Childhood Immigrants. The Review of Economics and Statistics 86:2.

Borjas, George J., 1985. Assimilation, Changes in Cohort Quality, and the Earnings of Immigrants. Journal of Labor Economics 3:4.

1987. Self-Selection and the Earnings of Immigrants. The American Economic Review 77:4. 1992. Ethnic Capital and Intergenerational Mobility. The Quarterly Journal of Economics 107:1. 
1995. Ethnicity, Neighborhoods, and Human-Capital Externalities. The American Economic Review 85:3.

2000. Ethnic Enclaves and Assimilation. Swedish Economic Policy Review 7.

2002. Homeownership in the Immigrant Population. Journal of Urban Economics 52:3.

Calvó-Armengol, Antoni and Matthew O. Jackson. 2004. The Effects of Social Networks on Employment and Inequality. The American Economic Review 94:3.

Cutler, David, Edward Glaeser and Jacob Vigdor. 2008. When are Ghettos Bad? Lessons from Immigrant Segregation in the United States. Journal of Urban Economics 63.

Edin, Per-Anders, Peter Fredriksson, and Olof Aslund. 2003. Ethnic Enclaves and the Economic Success of Immigrants - Evidence From a Natural Experiment. The Quarterly Journal of Economics 118:1.

Lazear, Edward P. 1999. Culture and Language. The Journal of Political Economy 107:6, part II.

Oreopoulos, Philip. 2011. Why Do Skilled Immigrants Struggle in the Labor Market? A Field Experiment with Thirteen Thousand Resumes. American Economic Journal: Economic Policy 3.

Pedace, Roberto and Stephanie Rohn. 2008. A Warm Embrace or a Cold Shoulder: Wage and Employment Outcomes in Ethnic Enclaves. U.S. Census Bureau, Center for Economic Studies Working Papers, CES 08-09.

Rosenzweig, Mark. 1995. Why are there Returns to Schooling? The American Economic Review 85:2.

Sousa, Liliana. 2011. Identifying Ethnic Enclaves Using Linked Employer-Household Data. http://paa2012.princeton.edu/papers/122369

Stock, James H., Jonathan H. Wright and Motohiro Yogo. 2002. A Survey of Weak Instruments and Weak Identification in Generalized Method of Moments. Journal of Business and Economic Statistics 20:4.

Wilson, Kenneth L. and Alejandro Portes. 1980. Immigrant Enclaves: An Analysis of the Labor Market Experience of Cubans in Miami. The American Journal of Sociology 86:2. 
Figures and Tables

Table 1. All Immigrants with LEHD Earnings Records in 2000 Who Immigrated as Adults and Reside in the Five Metropolitan Areas

\begin{tabular}{lc}
\hline & $\%$ \\
\hline \hline Male & 54.49 \\
Education & \\
8 years or less & 17.48 \\
Some High School & 14.21 \\
High School Diploma & 18.64 \\
Some College & 19.91 \\
College & 17.24 \\
Graduate/Professional Degree & 12.51 \\
Speaks English & 58.08 \\
English-speaking POB & 27.45 \\
Hispanic & 42.57 \\
Citizen & 47.27 \\
Workplace type & \\
Firm, more than 5 workers & 86.09 \\
Firm, 5 or fewer workers & 6.79 \\
Self-employed & 7.12 \\
\hline Sor &
\end{tabular}

Source: Author's calculations using the 2000 U.S. Census of Population and Housing 1-in-6 sample and the LEHD

Employer Characteristics File and Employment History File. Speaks English is a binary variable indicating whether the individual reports speaking English well or very well. English-speaking POB identifies country of origin where English is an official language and widely used among immigrants. 
Table 2. Mean Co-ethnic Exposure Rates and Earnings for Immigrants in the Workforce and who Reside in the Five Metropolitan Areas, Full Sample and by Education

\begin{tabular}{lcccccc} 
& & & \multicolumn{2}{c}{$\begin{array}{c}\text { More than High } \\
\text { School Diploma }\end{array}$} & \multicolumn{2}{c}{$\begin{array}{c}\text { High School } \\
\text { Diploma or Less }\end{array}$} \\
& Mean & S.E. & Mean & S.E. & Mean & S.E. \\
\hline \hline Residential Exposure Rate & 0.12 & 0.0002 & 0.08 & 0.0003 & 0.16 & 0.0004 \\
$\quad \begin{array}{l}\text { Workplace Exposure Rate } \\
\text { Residential Exposure Rate }\end{array}$ & 0.13 & 0.0003 & 0.09 & 0.0004 & 0.17 & 0.0004 \\
(1990), PMSA-level & 0.04 & 0.0001 & 0.02 & 0.0001 & 0.05 & 0.0002 \\
Residential Exposure Rate & 0.04 & 0.0001 & 0.03 & 0.0001 & 0.06 & 0.0002 \\
(2000), PMSA-level & & & & & & \\
Log Earnings (2000) & 9.91 & 0.0016 & 10.20 & 0.0023 & 9.61 & 0.0019 \\
$\quad$ without self-employed & 9.93 & 0.0016 & 10.24 & 0.0023 & 9.64 & 0.0019 \\
Age & 43.42 & 0.0165 & 42.75 & 0.0231 & 44.08 & 0.0235 \\
$\quad$ Years since migration & 15.34 & 0.0147 & 14.54 & 0.021 & 16.14 & 0.0205 \\
\hline Soll
\end{tabular}

Source: With the exception of the residential exposure rate in 1990, all values are the result of the author's calculations using the 2000 U.S. Census of Population and Housing 1-in-6 sample and the LEHD Employer Characteristics File and Employment History File. Residential exposure rate is calculated at the census tract level. Workplace exposure rate is calculated at the establishment level. Residential exposure rate in 1990 is calculated at the Primary Metropolitan Statistical Area, using the 1990 U.S. Census of Population and Housing, 5\% Sample. 
Table 3. Average Workplace Co-ethnic Exposure Rates, by Type of Workplace and Education

\begin{tabular}{lcccccc}
\hline & & & \multicolumn{2}{c}{$\begin{array}{c}\text { More than High } \\
\text { School Diploma }\end{array}$} & \multicolumn{2}{c}{$\begin{array}{c}\text { High School } \\
\text { Diploma or Less }\end{array}$} \\
\hline & Mean & S.E. & Mean & S.E. & Mean & S.E. \\
\hline \hline Firm-level & 0.1355 & 0.0003 & 0.0911 & 0.0003 & 0.1783 & 0.0004 \\
Self-employed & 0.0549 & 0.0001 & 0.0379 & 0.0001 & 0.0741 & 0.0002 \\
Block-level & 0.0785 & 0.0002 & 0.0669 & 0.0002 & 0.0889 & 0.0003 \\
Overall & 0.1270 & 0.0003 & 0.0854 & 0.0003 & 0.1651 & 0.0004 \\
\hline
\end{tabular}

Source: Author's calculations using the 2000 U.S. Census of Population and Housing 1-in-6 sample and the LEHD Employer Characteristics File and Employment History File. Workplace exposure rate is calculated at the census block of workplace for individuals with less than 5 coworkers. Workplace exposure rate is calculated at the establishment level for larger firms, and at the PMSA-industry cell for the self-employed. 
Table 4. Country or Region of Birth Distribution for All Immigrants Residing in the Five Metropolitan Areas in 2000 who had LEHD Earnings Records in 2000 and who Immigrated as Adults

\begin{tabular}{lrll}
\hline & $\%$ & & $\%$ \\
\hline \hline Canada & 1.09 & Puerto Rico & 2.61 \\
China & 3.32 & South Korea & 2.08 \\
Colombia & 2.61 & Taiwan & 1.96 \\
Cuba & 4.59 & United Kingdom & 1.63 \\
Dominican Republic & 3.91 & USSR Core & 3.14 \\
El Salvador & 3.59 & Vietnam & 2.49 \\
Germany & 0.89 & Regions of Birth: & \\
Guatemala & 1.86 & Africa & 2.45 \\
Haiti & 2.54 & Caribbean & 2.27 \\
India & 4.63 & Central America & 3.05 \\
Iran & 1.15 & Central Asia & 1.57 \\
Italy & 1.03 & Middle East/North Africa & 2.21 \\
Jamaica & 3.20 & Oceania & 0.30 \\
Japan & 1.13 & Socialist Europe & 2.12 \\
Mexico & 15.93 & South America & 6.83 \\
Philippines & 6.01 & South East Asia & 2.02 \\
Poland & 2.25 & Western Europe & 3.55 \\
\hline Soure: Aun
\end{tabular}

Source: Author's calculations based on 2000 U.S. Census of Population and Housing. Immigrants from smaller country of origin groups are aggregated to region of births group. These region of birth groups exclude the country of birth groups listed above. 
Table 5. The Relationship Between Immigrant Earnings in 2000 and Co-ethnic Exposure Rates in the Neighborhood and in the Workplace

\begin{tabular}{|c|c|c|}
\hline & Residential Quartiles & Workplace Quartiles \\
\hline Quartile $=2$ & $\begin{array}{rl}-0.0351 & * * * \\
(0.0105) & \end{array}$ & $\begin{array}{r}0.0581 \quad * * * \\
(0.0140)\end{array}$ \\
\hline Quartile $=3$ & $\begin{array}{rl}-0.1020 & * * * \\
(0.0151) & \end{array}$ & $\begin{array}{r}0.0381 \\
(0.0218)\end{array}$ \\
\hline Quartile $=4$ & $\begin{array}{r}-0.1321 \quad * * * \\
(0.0199)\end{array}$ & $\begin{array}{r}-0.0277 \\
(0.0317)\end{array}$ \\
\hline R-squared & 0.2766 & 0.2757 \\
\hline
\end{tabular}

Source: The values reported in this table are the OLS coefficients on the residential and workplace quartiles from two separate wage regressions on log of wages in 2000. Log wages was regressed separately on residential and workplace quartiles. Controls were included for MSA of residence, place of birth dummy variable, age, age-squared, gender, Hispanic ethnicity, years since migration and its square, citizenship, employer type, firm size, English skills, English is an official language in the country of birth, education, and the estimated minimum education completed in the U.S. These regressions exclude the self-employed. Clustered robust standard errors are reported in parentheses.

$* * * \mathrm{p}<0.01, * * \mathrm{p}<0.05, * \mathrm{p}<0.1$ 
Table 6. Distribution of Quartile of Residential Own-exposure Interacted with Quartile of Workplace Own-exposure

\begin{tabular}{cccc}
\hline \multicolumn{2}{c}{ Quartile of Own-exposure } & All & Not Self-employed \\
\hline Residential & Workplace & $\%$ & $\%$ \\
\hline 1 & 1 & 13.01 & 12.71 \\
1 & 2 & 6.73 & 6.56 \\
1 & 3 & 3.45 & 3.47 \\
1 & 4 & 1.82 & 1.93 \\
\hline 2 & 1 & 7.08 & 7.1 \\
2 & 2 & 8.36 & 7.95 \\
2 & 3 & 6.19 & 6.15 \\
2 & 4 & 3.38 & 3.57 \\
\hline 3 & 1 & 3.57 & 3.77 \\
3 & 2 & 6.61 & 6.33 \\
3 & 3 & 8.38 & 8.25 \\
3 & 4 & 6.44 & 6.79 \\
\hline 4 & 1 & 1.34 & 1.52 \\
4 & 2 & 3.31 & 3.07 \\
4 & 3 & 6.99 & 6.87 \\
4 & 4 & 13.36 & 13.95 \\
\hline
\end{tabular}

Source: Author's calculations based on 2000 U.S. Census of Population and Housing and LEHD Employment History File and Employer Characteristics File. For both the residential and workplace own-exposure rates, each individual is assigned to a quartile where quartile 1 includes the $25 \%$ of individuals with the lowest values of co-ethnic exposure rates and each subsequent quartile assigned to individuals with higher values of co-ethnic exposure rates. Quartiles are calculated independently for each of the two samples. 
Table 7. The Relationship Between Co-ethnic Exposure Rate Quartiles (in the Neighborhood and the Workplace) on Immigrant Earnings in 2000

\begin{tabular}{|c|c|c|c|c|c|}
\hline Residential Quartile = 1 & & & Residential Quartile = 3 & & \\
\hline Work Quartile = 1 & omitted & & Work Quartile = 1 & $\begin{array}{r}-0.1044 \\
(0.0187)\end{array}$ & $* * *$ \\
\hline Work Quartile = 2 & $\begin{array}{r}0.0930 \\
(0.0174)\end{array}$ & $* * *$ & Work Quartile = 2 & $\begin{array}{r}-0.0394 \\
(0.0195)\end{array}$ & \\
\hline Work Quartile = 3 & $\begin{array}{r}0.0880 \\
(0.0267)\end{array}$ & $* * *$ & Work Quartile = 3 & $\begin{array}{r}-0.0421 \\
(0.0243)\end{array}$ & $*$ \\
\hline Work Quartile = 4 & $\begin{array}{r}-0.0613 \\
(0.0289) \\
\end{array}$ & $* *$ & Work Quartile = 4 & $\begin{array}{r}-0.0998 \\
(0.0388)\end{array}$ & $* *$ \\
\hline Residential Quartile = 2 & & & Residential Quartile = 4 & & \\
\hline Work Quartile = 1 & $\begin{array}{r}-0.0441 \\
(0.0143)\end{array}$ & $* * *$ & Work Quartile $=1$ & $\begin{array}{r}-0.1296 \\
(0.0224)\end{array}$ & $* * *$ \\
\hline Work Quartile = 2 & $\begin{array}{r}0.0227 \\
(0.0203)\end{array}$ & & Work Quartile = 2 & $\begin{array}{r}-0.0726 \\
(0.0273)\end{array}$ & $* * *$ \\
\hline Work Quartile = 3 & $\begin{array}{r}0.0443 \\
(0.0259)\end{array}$ & $*$ & Work Quartile = 3 & $\begin{array}{r}-0.0922 \\
(0.0299)\end{array}$ & $* * *$ \\
\hline Work Quartile = 4 & $\begin{array}{r}-0.0380 \\
(0.0363)\end{array}$ & & Work Quartile = 4 & $\begin{array}{r}-0.1072 \\
(0.0374)\end{array}$ & $* * *$ \\
\hline
\end{tabular}

Source: The values reported in this table are the OLS coefficients on a categorical variable representing each of the 16 different combinations of residential and workplace quartiles (with R-squared equal to 0.2778). The dependent variable is log of wages in 2000. Controls were included for MSA of residence, place of birth dummy variables, age, age-squared, gender, Hispanic ethnicity, years since migration and its square, citizenship, employer type, firm size, English skills, English is an official language in the country of birth, education, and the estimated minimum education in the U.S. This regression excludes the selfemployed.

Clustered robust standard errors are reported in parentheses.

$* * * \mathrm{p}<0.01, * * \mathrm{p}<0.05, * \mathrm{p}<0.1$ 
Table 8. Proportion of Immigrants by Age at Arrival, for Different Country and Region of Birth Groups

\begin{tabular}{|c|c|c|c|}
\hline & Under 18 & $18-24$ & 25 and over \\
\hline Canada & 0.4293 & 0.2024 & 0.3684 \\
\hline China & 0.1465 & 0.2173 & 0.6362 \\
\hline Colombia & 0.2673 & 0.2750 & 0.4577 \\
\hline Cuba & 0.3734 & 0.1472 & 0.4794 \\
\hline Dominican Republic & 0.3256 & 0.2679 & 0.4065 \\
\hline El Salvador & 0.3409 & 0.3591 & 0.3001 \\
\hline Germany & 0.5538 & 0.2129 & 0.2333 \\
\hline Guatemala & 0.2953 & 0.3805 & 0.3242 \\
\hline Haiti & 0.2549 & 0.2701 & 0.4749 \\
\hline India & 0.1461 & 0.3043 & 0.5496 \\
\hline Iran & 0.2918 & 0.2647 & 0.4435 \\
\hline Italy & 0.5116 & 0.2321 & 0.2563 \\
\hline Jamaica & 0.3156 & 0.2157 & 0.4687 \\
\hline Japan & 0.2515 & 0.2410 & 0.5075 \\
\hline Mexico & 0.4465 & 0.3408 & 0.2128 \\
\hline Philippines & 0.2202 & 0.2374 & 0.5424 \\
\hline Poland & 0.2246 & 0.2318 & 0.5436 \\
\hline South Korea & 0.3799 & 0.1645 & 0.4555 \\
\hline Taiwan & 0.2699 & 0.2347 & 0.4954 \\
\hline United Kingdom & 0.2653 & 0.2238 & 0.5110 \\
\hline USSR Core & 0.1800 & 0.1558 & 0.6643 \\
\hline Vietnam & 0.3446 & 0.2564 & 0.3990 \\
\hline Africa & 0.1551 & 0.3028 & 0.5421 \\
\hline Caribbean & 0.3027 & 0.2629 & 0.4344 \\
\hline Central America & 0.3369 & 0.2882 & 0.3749 \\
\hline Central Asia & 0.2718 & 0.2615 & 0.4667 \\
\hline Middle East/North Africa & 0.2941 & 0.2815 & 0.4244 \\
\hline Oceania & 0.2794 & 0.2487 & 0.4719 \\
\hline Socialist Europe & 0.2642 & 0.2370 & 0.4988 \\
\hline South America & 0.2759 & 0.2672 & 0.4568 \\
\hline South East Asia & 0.3065 & 0.2306 & 0.4630 \\
\hline Western Europe & 0.3407 & 0.2907 & 0.3685 \\
\hline Total & 0.3233 & 0.2697 & 0.4070 \\
\hline
\end{tabular}

Source: Author's calculations based on 2000 U.S. Census of Population and Housing. 
Table 9. The Effects of Residential and Workplace Co-ethnic Exposure Rates on Log of Earnings in 2000

\begin{tabular}{|c|c|c|c|c|c|c|}
\hline & \multicolumn{2}{|c|}{ Full Sample } & \multicolumn{2}{|c|}{$\begin{array}{l}\text { More than High School } \\
\text { Diploma }\end{array}$} & \multicolumn{2}{|c|}{$\begin{array}{l}\text { High School Diploma or } \\
\text { Less }\end{array}$} \\
\hline $\begin{array}{l}\text { Residential Exposure } \\
\text { Rate }\end{array}$ & $\begin{array}{c}-0.2481 * * * \\
(0.051)\end{array}$ & & $\begin{array}{c}-0.4597 * * * \\
(0.070)\end{array}$ & & $\begin{array}{c}-0.1410 * * * \\
(0.041)\end{array}$ & \\
\hline $\begin{array}{l}\text { Workplace Exposure } \\
\text { Rate }\end{array}$ & & $\begin{array}{c}-0.2030 * * \\
(0.096)\end{array}$ & & $\begin{array}{c}-0.1710^{*} \\
(0.097)\end{array}$ & & $\begin{array}{c}-0.1832 * * \\
(0.089)\end{array}$ \\
\hline $\begin{array}{l}\text { Years Since Migration } \\
\text { (YSM) }\end{array}$ & $\begin{array}{c}0.0240 * * * \\
(0.002)\end{array}$ & $\begin{array}{c}0.0235^{* * *} \\
(0.002)\end{array}$ & $\begin{array}{c}0.0236 * * * \\
(0.004)\end{array}$ & $\begin{array}{c}0.0232 * * * \\
(0.004)\end{array}$ & $\begin{array}{l}0.0219 * * * \\
(0.001)\end{array}$ & $\begin{array}{c}0.0217 * * * \\
(0.001)\end{array}$ \\
\hline YSM - squared & $\begin{array}{c}-0.0003 * * * \\
(0.000)\end{array}$ & $\begin{array}{c}-0.0003 * * * \\
(0.000)\end{array}$ & $\begin{array}{c}-0.0002 * * \\
(0.000)\end{array}$ & $\begin{array}{c}-0.0002 * * \\
(0.000)\end{array}$ & $\begin{array}{c}-0.0003 * * * \\
(0.000)\end{array}$ & $\begin{array}{c}-0.0003 * * * \\
(0.000)\end{array}$ \\
\hline Speaks English & $\begin{array}{c}0.1530 * * * \\
(0.015)\end{array}$ & $\begin{array}{c}0.1510 * * * \\
(0.014)\end{array}$ & $\begin{array}{c}0.1672 * * * \\
(0.023)\end{array}$ & $\begin{array}{c}0.1700 * * * \\
(0.023)\end{array}$ & $\begin{array}{c}0.1378 * * * \\
(0.010)\end{array}$ & $\begin{array}{c}0.1345 * * * \\
(0.011)\end{array}$ \\
\hline English-speaking POB & $\begin{array}{c}0.2025 * * * \\
(0.020)\end{array}$ & $\begin{array}{c}0.1966 * * * \\
(0.019)\end{array}$ & $\begin{array}{c}0.1984 * * * \\
(0.018)\end{array}$ & $\begin{array}{c}0.1922 * * * \\
(0.018)\end{array}$ & $\begin{array}{c}0.2160 * * * \\
(0.030)\end{array}$ & $\begin{array}{c}0.2112 * * * \\
(0.029)\end{array}$ \\
\hline Some High School & $\begin{array}{c}0.0495 * * * \\
(0.009)\end{array}$ & $\begin{array}{c}0.0495 * * * \\
(0.008)\end{array}$ & - & - & $\begin{array}{c}0.0654 * * * \\
(0.007)\end{array}$ & $\begin{array}{c}0.0642 * * * \\
(0.006)\end{array}$ \\
\hline High School Diploma & $\begin{array}{c}0.1000 * * * \\
(0.015)\end{array}$ & $\begin{array}{c}0.1006^{* * *} \\
(0.014)\end{array}$ & - & - & $\begin{array}{c}0.1309 * * * \\
(0.011)\end{array}$ & $\begin{array}{c}0.1294 * * * \\
(0.029)\end{array}$ \\
\hline Some College & $\begin{array}{c}0.2475 * * * \\
(0.022)\end{array}$ & $\begin{array}{c}0.2474 * * * \\
(0.021)\end{array}$ & - & - & - & - \\
\hline College & $\begin{array}{c}0.5789 * * * \\
(0.030)\end{array}$ & $\begin{array}{c}0.5797 * * * \\
(0.028)\end{array}$ & $\begin{array}{c}0.3013 * * * \\
(0.018)\end{array}$ & $\begin{array}{c}0.3050 * * * \\
(0.018)\end{array}$ & - & - \\
\hline Graduate Degree & $\begin{array}{c}0.8283 * * * \\
(0.046)\end{array}$ & $\begin{array}{c}0.8284 * * * \\
(0.043)\end{array}$ & $\begin{array}{c}0.5453 * * * \\
(0.027)\end{array}$ & $\begin{array}{c}0.5507 * * * \\
(0.027)\end{array}$ & - & - \\
\hline Some College in U.S. & $\begin{array}{l}-0.0185 \\
(0.016)\end{array}$ & $\begin{array}{l}-0.0190 \\
(0.016)\end{array}$ & $\begin{array}{l}-0.0209 \\
(0.021)\end{array}$ & $\begin{array}{l}-0.0226 \\
(0.021)\end{array}$ & - & - \\
\hline College in U.S. & $\begin{array}{c}0.0559 * * \\
(0.030)\end{array}$ & $\begin{array}{c}0.0540 * * \\
(0.026)\end{array}$ & $\begin{array}{l}0.0434 \\
(0.025)\end{array}$ & $\begin{array}{c}0.0441 * \\
(0.025)\end{array}$ & - & - \\
\hline Graduate School in U.S. & $\begin{array}{c}0.0532 * * \\
(0.027)\end{array}$ & $\begin{array}{l}0.0528 \\
(0.026)\end{array}$ & $\begin{array}{l}-0.0229 \\
(0.024)\end{array}$ & $\begin{array}{l}-0.0214 \\
(0.024)\end{array}$ & - & - \\
\hline Small firm & $\begin{array}{c}-0.3321 * * * \\
(0.017)\end{array}$ & $\begin{array}{c}-0.3654 * * * \\
(0.018)\end{array}$ & $\begin{array}{c}-0.3385 * * * \\
(0.017)\end{array}$ & $\begin{array}{c}-0.3626^{* * * *} \\
(0.020)\end{array}$ & $\begin{array}{c}-0.3299 * * * \\
(0.025)\end{array}$ & $\begin{array}{c}-0.3640 * * * \\
(0.021)\end{array}$ \\
\hline $\operatorname{Ln}($ firmsize $)$ & $\begin{array}{c}0.0255 * * * \\
(0.003)\end{array}$ & $\begin{array}{c}0.0213 * * * \\
(0.002)\end{array}$ & $\begin{array}{c}0.0257 * * * \\
(0.002)\end{array}$ & $\begin{array}{c}0.0225 * * * \\
(0.002)\end{array}$ & $\begin{array}{c}0.0223 * * * \\
(0.004)\end{array}$ & $\begin{array}{c}0.0183 * * * \\
(0.003)\end{array}$ \\
\hline Observations & $\sim 450,000$ & $\sim 450,000$ & $\sim 220,000$ & $\sim 220,000$ & $\sim 230,000$ & $\sim 230,000$ \\
\hline R-squared & 0.277 & 0.278 & 0.225 & 0.224 & 0.195 & 0.196 \\
\hline $\begin{array}{l}\text { Source: All regressions also inc } \\
\text { residence identifiers. Data are c } \\
\text { Employer Characteristics File a } \\
\text { workplaces and at the Census b } \\
\text { regressions. } \\
\text { Clustered robust standard error } \\
* * * \mathrm{p}<0.01, * * \mathrm{p}<0.05, * \mathrm{p}<0.1\end{array}$ & $\begin{array}{l}\text { ge, age-squared } \\
\text { cted from the } 2 \\
\text { ployment Histo } \\
\text { workplace and } \\
\text { ported in paren }\end{array}$ & $\begin{array}{l}\text { sex, Hispanic } \\
0 \text { U.S. Census } \\
\text { File. Workpl } \\
\text { ndustry level f } \\
\text { eses. }\end{array}$ & $\begin{array}{l}\text { icity, U.S. c } \\
\text { Population } \\
\text { exposure ra } \\
\text { maller work }\end{array}$ & $\begin{array}{l}\text { nship status, } \\
\text { Housing 1-in- } \\
\text { calculated at } \\
\text { es. The self- }\end{array}$ & $\begin{array}{l}\text { ntry of birth } \\
\text { ample and th } \\
\text { establishmer } \\
\text { loyed are ex }\end{array}$ & $\begin{array}{l}\text { MSA of } \\
\text { EHD } \\
\text { vel for large } \\
\text { led from these }\end{array}$ \\
\hline
\end{tabular}


Table 10. The Effects of Residential and Workplace Co-ethnic Exposure Rates on Log of Earnings in 2000, Including the Self-Employed

\begin{tabular}{|c|c|c|}
\hline $\begin{array}{l}\text { Residential Exposure } \\
\text { Rate }\end{array}$ & $\begin{array}{c}-0.2569 * * * \\
(0.050)\end{array}$ & \\
\hline $\begin{array}{l}\text { Workplace Exposure } \\
\text { Rate }\end{array}$ & & $\begin{array}{c}-0.2290 * * * \\
(0.097)\end{array}$ \\
\hline Observations & $\sim 500,000$ & $\sim 500,000$ \\
\hline R-squared & 0.2696 & 0.2699 \\
\hline \multicolumn{3}{|c|}{ More than High School Diploma } \\
\hline $\begin{array}{l}\text { Residential Exposure } \\
\text { Rate }\end{array}$ & $\begin{array}{c}-0.4685 * * * \\
(0.067)\end{array}$ & \\
\hline $\begin{array}{l}\text { Workplace Exposure } \\
\text { Rate }\end{array}$ & & $\begin{array}{c}-0.2051 * * \\
(0.097)\end{array}$ \\
\hline Observations & $\sim 250,000$ & $\sim 250,000$ \\
\hline R-squared & 0.2221 & 0.2211 \\
\hline \multicolumn{3}{|c|}{ High School Diploma or Less } \\
\hline $\begin{array}{l}\text { Residential Exposure } \\
\text { Rate }\end{array}$ & $\begin{array}{c}-0.1513 * * * \\
(0.040)\end{array}$ & \\
\hline $\begin{array}{l}\text { Workplace Exposure } \\
\text { Rate }\end{array}$ & & $\begin{array}{c}-0.2024 * * \\
(0.091) \\
\end{array}$ \\
\hline Observations & $\sim 250,000$ & $\sim 250,000$ \\
\hline R-squared & 0.1925 & 0.1933 \\
\hline \multicolumn{3}{|c|}{$\begin{array}{l}\text { Source: This table reports the results from six separate OLS log earnings regressions. These } \\
\text { regressions control for sex, age, age-squared, years since migration and its square, Hispanic } \\
\text { ethnicity, citizenship status, educational attainment, estimated U.S. educational attainment, } \\
\text { employer type, self-employment indicator, firm size, English-language ability, indicator for } \\
\text { English is an official language in country of birth, country of birth, and MSA of residence. Data } \\
\text { are constructed from the } 2000 \text { U.S. Census of Population and Housing 1-in-6 sample and the } \\
\text { LEHD Employer Characteristics File and Employment History File. Workplace exposure rate is } \\
\text { calculated at the establishment level for large workplaces, at the Census block of workplace and } \\
\text { industry level for smaller workplaces, and at the PMSA-industry cell for the self-employed. } \\
\text { Note that only the wages that were not from self-employment are included for the self- } \\
\text { employed. } \\
\text { Clustered robust standard errors are reported in parentheses. } \\
* * * \text { p }<0.01, * * p<0.05, * \text { p }<0.10\end{array}$} \\
\hline
\end{tabular}


Table 11. The Effects of Residential and Workplace Co-ethnic Exposure Rates on Log of Earnings in 2000: Instrumental Variable Analysis Using 1990 PMSA Co-ethnic Exposure Rate

\begin{tabular}{|c|c|c|}
\hline Residential Exposure Rate & $\begin{array}{l}-0.1720^{*} \\
(0.099)\end{array}$ & \\
\hline Workplace Exposure Rate & & $\begin{array}{l}-0.2799 * \\
(0.159)\end{array}$ \\
\hline R-squared & 0.2772 & 0.2774 \\
\hline First-stage F-test & $5633.10^{* * *}$ & $3083.00 * * *$ \\
\hline First-stage T-test & 174.05 & 94.78 \\
\hline \multicolumn{3}{|c|}{ More than High School Diplome } \\
\hline Residential Exposure Rate & $\begin{array}{l}-0.3641 * * \\
(0.151)\end{array}$ & \\
\hline Workplace Exposure Rate & & $\begin{array}{l}-0.5988^{* * *} \\
(0.2260)\end{array}$ \\
\hline R-squared & 0.2247 & 0.2197 \\
\hline First-stage F-test & $1730.07 * * *$ & $777.14 * * *$ \\
\hline First-stage T-test & 111.04 & 60.51 \\
\hline \multicolumn{3}{|c|}{ High School Diploma or Less } \\
\hline Residential Exposure Rate & $\begin{array}{l}-0.0305 \\
(0.096)\end{array}$ & \\
\hline Workplace Exposure Rate & & $\begin{array}{l}-0.0497 \\
(0.158)\end{array}$ \\
\hline R-squared & 0.1948 & 0.1952 \\
\hline First-stage F-test & $4035.15^{* * *}$ & $2356.76^{* * *}$ \\
\hline First-stage T-test & 134.38 & 72.27 \\
\hline
\end{tabular}

Source: All above coefficients are from two-stage least square regressions where co-ethnic exposure rates are instrumented using the 1990 PMSA-level co-ethnic exposure rate. These regressions control for sex, age, age-squared, years since migration and its square, Hispanic ethnicity, citizenship status, educational attainment, estimated U.S. educational attainment, employer type, self-employment indicator, firm size, English-language ability, indicator for English is an official language in country of birth, country of birth, and MSA of residence. Data are constructed from the 2000 U.S. Census of Population and Housing 1-in-6 sample and the LEHD Employer Characteristics File and Employment History File. Workplace exposure rate is calculated at the establishment level for large workplaces, and at the Census block of workplace and industry level for smaller workplaces. The self-employed are excluded for these regressions.

Clustered robust standard errors are reported in parentheses.

$* * * \mathrm{p}<0.01, * * \mathrm{p}<0.05, * \mathrm{p}<0.1$ 
Table 12. Distribution of Occupational Groups, by Work Quartiles

\section{Workplace Quartile}

\begin{tabular}{lrrrrr} 
Occupational Group & 1 & 2 & 3 & 4 & Overall \\
\cline { 2 - 5 } & $39.7 \%$ & $37.0 \%$ & $23.4 \%$ & $15.7 \%$ & $28.9 \%$ \\
Management, Professional, and Related & $15.4 \%$ & $18.3 \%$ & $24.3 \%$ & $20.7 \%$ & $19.7 \%$ \\
Services & $23.5 \%$ & $21.4 \%$ & $18.7 \%$ & $15.4 \%$ & $19.8 \%$ \\
Sales and Office Occupations & $7.3 \%$ & $7.1 \%$ & $9.1 \%$ & $10.8 \%$ & $8.6 \%$ \\
Construction, Extraction, and Maintenance & $14.0 \%$ & $16.0 \%$ & $24.2 \%$ & $36.1 \%$ & $22.6 \%$ \\
Production, Transportation, and Material Moving & &
\end{tabular}

Source: Author's calculations based on 2000 U.S. Census of Population and Housing and LEHD Employment History File and Employer Characteristics File. Each individual is assigned to a workplace quartile where quartile 1 includes the $25 \%$ of individuals with the lowest values of workplace exposure rates and each subsequent quartile assigned to individuals with higher values of co-ethnic exposure rates. The self-employed are excluded. 
Table 13. The Effects of Residential and Workplace Co-ethnic Exposure Rates on Log of Earnings in 2000 After Controlling for Occupation: Instrumental Variable Analysis Using 1990 PMSA

Co-ethnic Exposure Rate

\begin{tabular}{|c|c|c|c|c|}
\hline \multirow[b]{2}{*}{ Residential Exposure Rate } & \multicolumn{2}{|c|}{ OLS } & \multicolumn{2}{|c|}{ IV } \\
\hline & $\begin{array}{l}-0.2245 * * * \\
(0.045)\end{array}$ & & $\begin{array}{l}-0.1824 * \\
(0.094)\end{array}$ & \\
\hline Workplace Exposure Rate & & $\begin{array}{l}-.1933 * * \\
(0.091)\end{array}$ & & $\begin{array}{l}-0.2953 * \\
(0.154)\end{array}$ \\
\hline R-squared & 0.3022 & 0.3024 & 0.3022 & 0.3022 \\
\hline First-stage F-test & & & $5138.00 * * *$ & $2850.35^{* * *}$ \\
\hline \multirow[t]{3}{*}{ First-stage T-test } & & & 174.50 & 95.70 \\
\hline & \multicolumn{4}{|c|}{ More than High School Diploma } \\
\hline & \multicolumn{2}{|c|}{ OLS } & \multicolumn{2}{|c|}{ IV } \\
\hline Residential Exposure Rate & $\begin{array}{l}-0.3656 * * * \\
(0.056)\end{array}$ & & $\begin{array}{l}-0.3070^{* *} \\
(0.125)\end{array}$ & \\
\hline Workplace Exposure Rate & & $\begin{array}{l}-0.1428^{*} \\
(0.081)\end{array}$ & & $\begin{array}{l}-0.5043^{* * *} \\
(0.190)\end{array}$ \\
\hline R-squared & 0.2677 & 0.2670 & 0.2677 & 0.264 \\
\hline First-stage F-test & & & $1567.13^{* * *}$ & $706.57 * * *$ \\
\hline First-stage T-test & & & 110.86 & 60.51 \\
\hline
\end{tabular}

High School Diploma or Less

\begin{tabular}{lllll}
\hline \hline & \multicolumn{2}{c}{ OLS } \\
\cline { 2 - 5 } Residential Exposure Rate & $-0.1444^{* * *}$ & & -0.0624 \\
& $(0.039)$ & & $(0.100)$ & \\
Workplace Exposure Rate & & $-0.1858^{* *}$ & & -0.1005 \\
& & $(0.090)$ & $0.167)$ \\
\hline R-squared & 0.2020 & 0.2027 & 0.2018 & 0.2025 \\
First-stage F-test & & & $3625.29^{* * * *}$ & $2155.60^{* * * *}$ \\
First-stage T-test & & & 135.38 & 73.64 \\
\hline S
\end{tabular}

Source: This table reports the coefficients from three OLS regressions on the left column and three two-stage least square regressions where residential or workplace co-ethnic exposure rates are instrumented using the 1990 PMSA-level co-ethnic exposure rate. These regressions control for occupational group, sex, age, agesquared, years since migration and its square, Hispanic ethnicity, citizenship status, educational attainment, estimated U.S. educational attainment, employer type, self-employment indicator, firm size, English-language ability, indicator for English is an official language in country of birth, country of birth, and MSA of residence. Data are constructed from the 2000 U.S. Census of Population and Housing 1-in-6 sample and the LEHD Employer Characteristics File and Employment History File. Workplace exposure rate is calculated at the establishment level for large workplaces, and at the Census block of workplace and industry level for smaller workplaces. The self-employed are excluded.

Clustered robust standard errors are reported in parentheses.

$* * * \mathrm{p}<0.01, * * \mathrm{p}<0.05, * \mathrm{p}<0.10$ 
Table 14. The Effects of Residential and Workplace Co-ethnic Exposure Rates on Log of Earnings in 2000 After Controlling for Proportion of Coworkers who are also Neighbors: Instrumental Variable Analysis Using 1990 PMSA Co-ethnic Exposure Rate

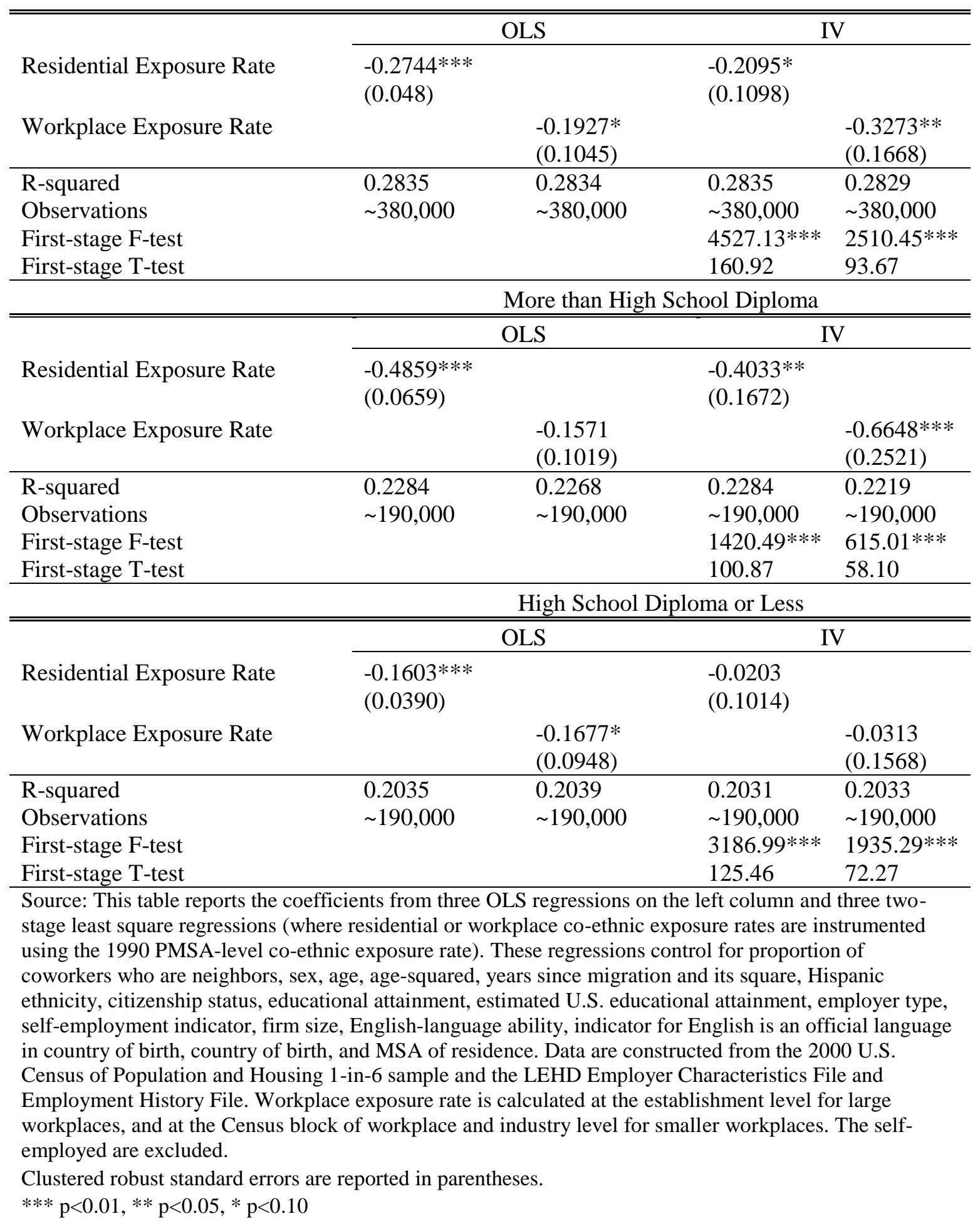


Figure 1. Earnings for U.S. Natives and Immigrants Ages 18 - 70 Residing in Five U.S. Urban Areas in 2000

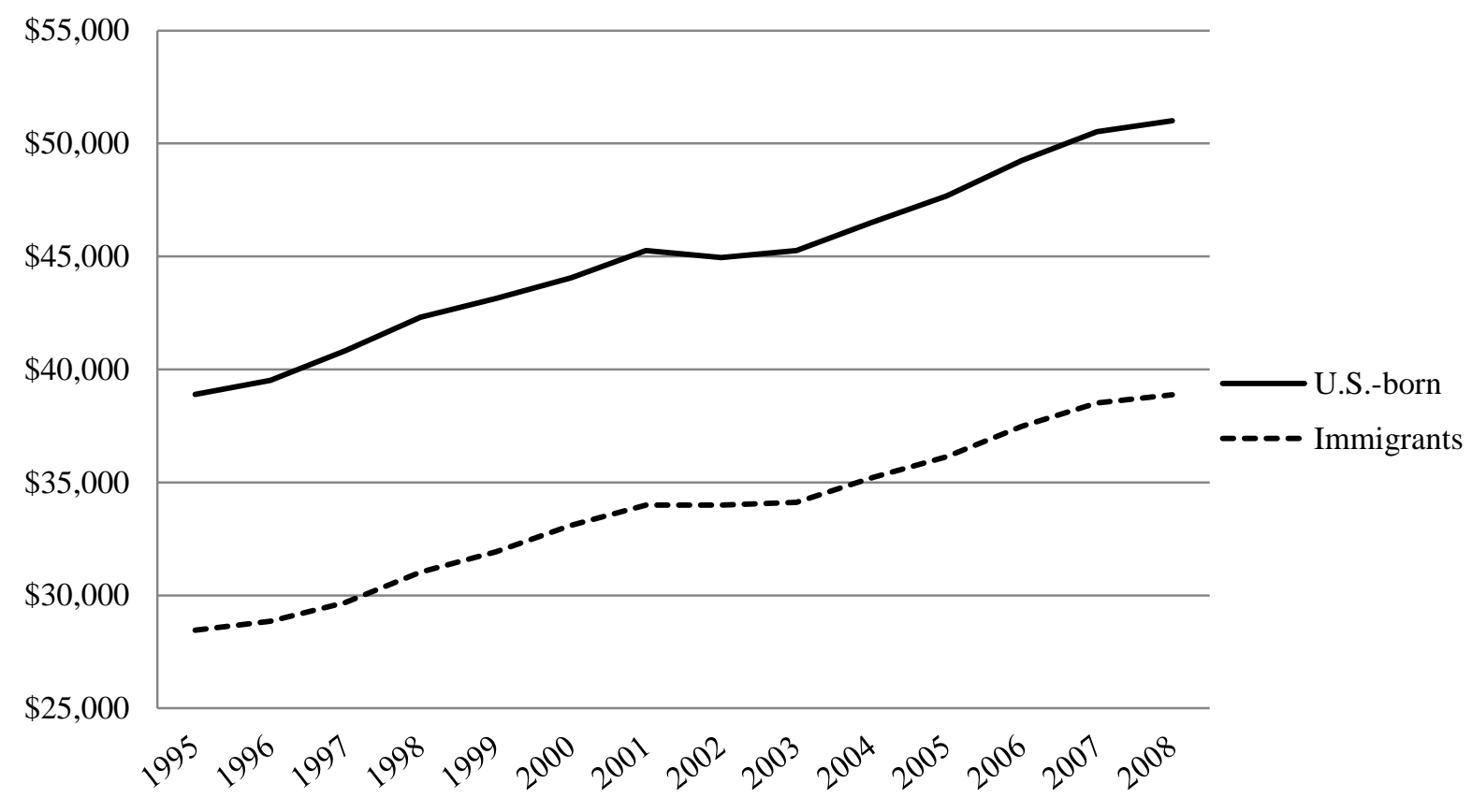

Source: Author's calculations from the LEHD Employment History File. All values have been adjusted for inflation to reflect year 2000 dollars. Only those immigrants who were at least 18 when they first arrived in the U.S. are reported. 
Figure 2. Earnings Between 1995-2008 for U.S. Natives and Immigrants, by Age

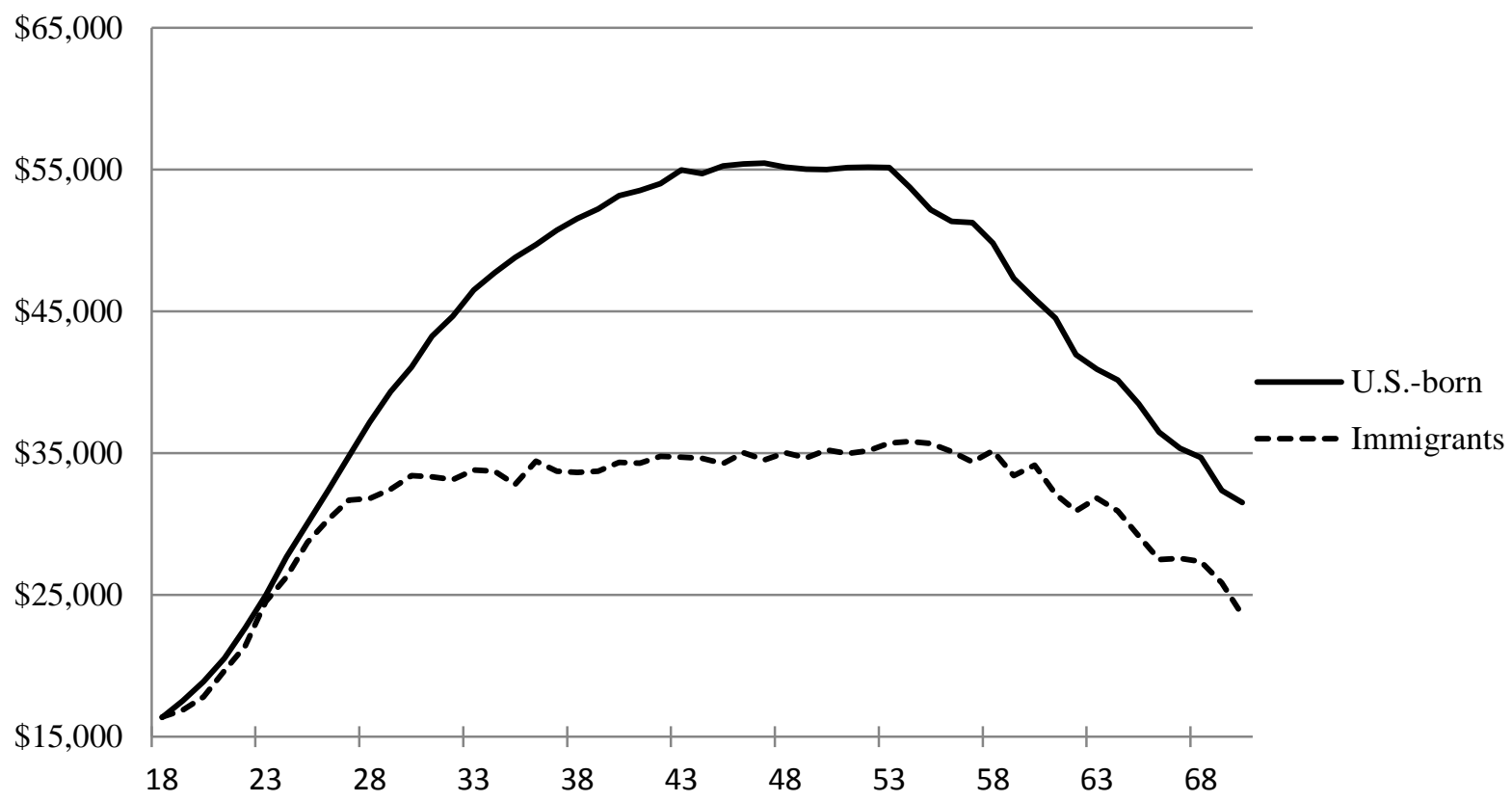

Source: Author's calculations from the LEHD Employment History File. All values have been adjusted for inflation to reflect year 2000 dollars. Only those immigrants who were at least 18 when they first arrived in the U.S. are reported. 


\section{Figure 3. Earnings Between 1995-2008 for U.S. Natives and Immigrants, by Arrival Cohort and by Age}

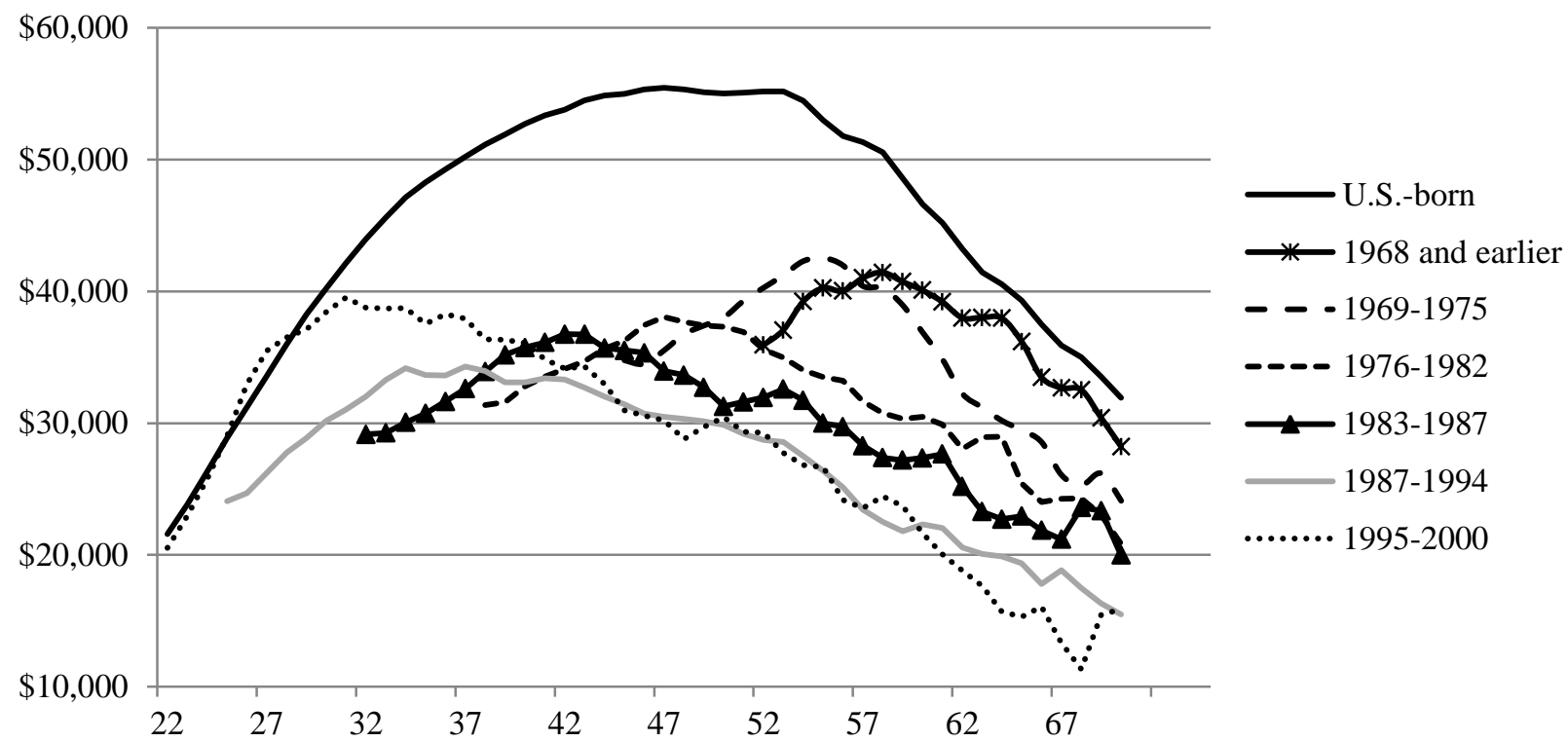

Source: Author's calculations from the LEHD Employment History File. All values have been adjusted for inflation to reflect year 2000 dollars. This figure has been smoothed by using rolling 2 year average income. Only those immigrants 


\section{Figure 4. Mean Annual Earnings by Quartile of Residential and Workplace}

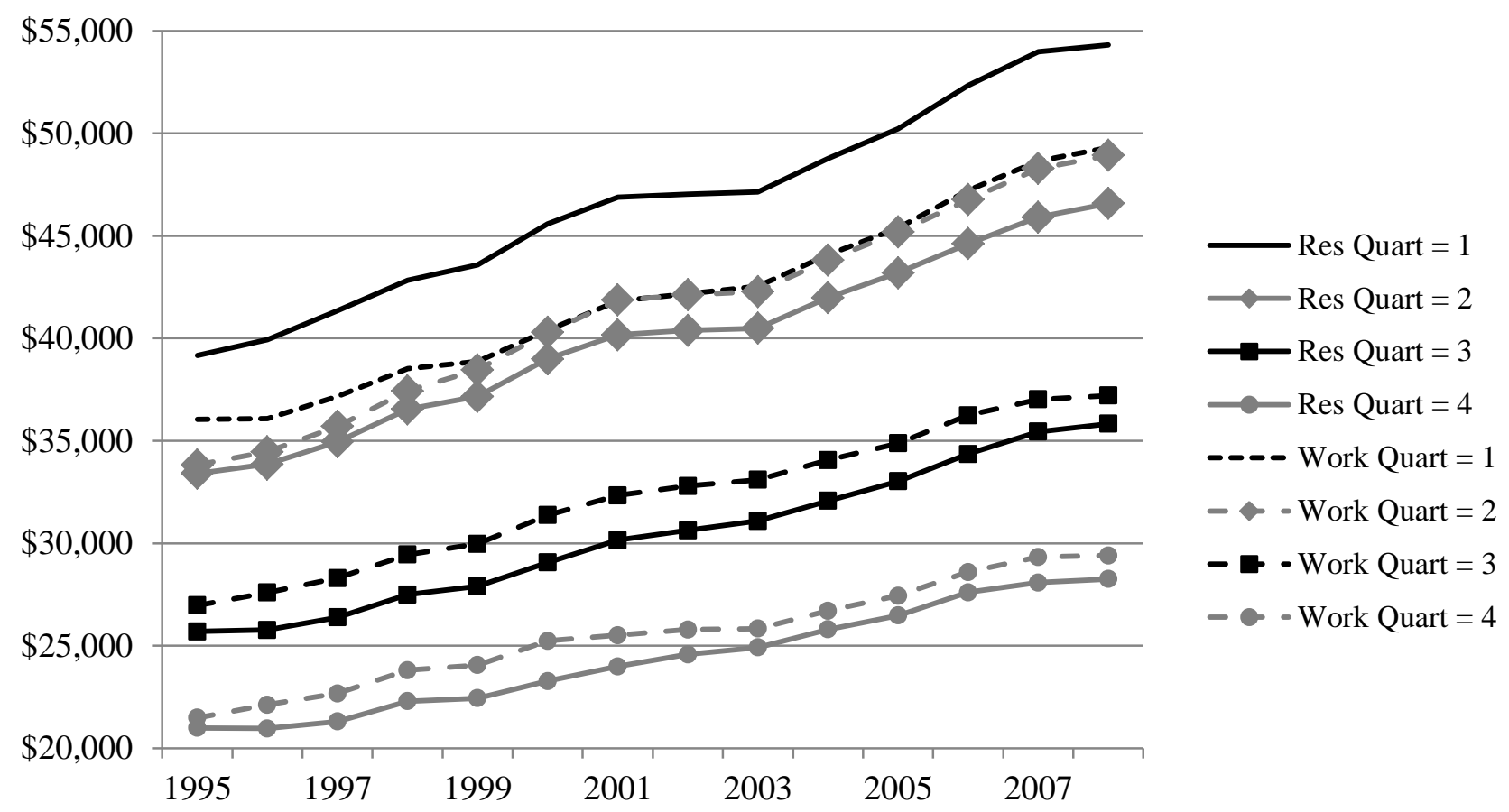

Source: Author's calculations from the LEHD Employment History File. All values have been adjusted for inflation to reflect year 2000 dollars. Only those immigrants who were at least 18 when they first arrived in the U.S. are reported. This figure was also created for only those immigrants who reported not being self-employed in 2000, but the average earnings do not differ substantially from those reported here. 
Figure 5. Annual Earnings Between 1995-2008, for Immigrants in High and Low Co-ethnic Residential Areas, by Quartile of Co-ethnic Workplace Exposure and Year

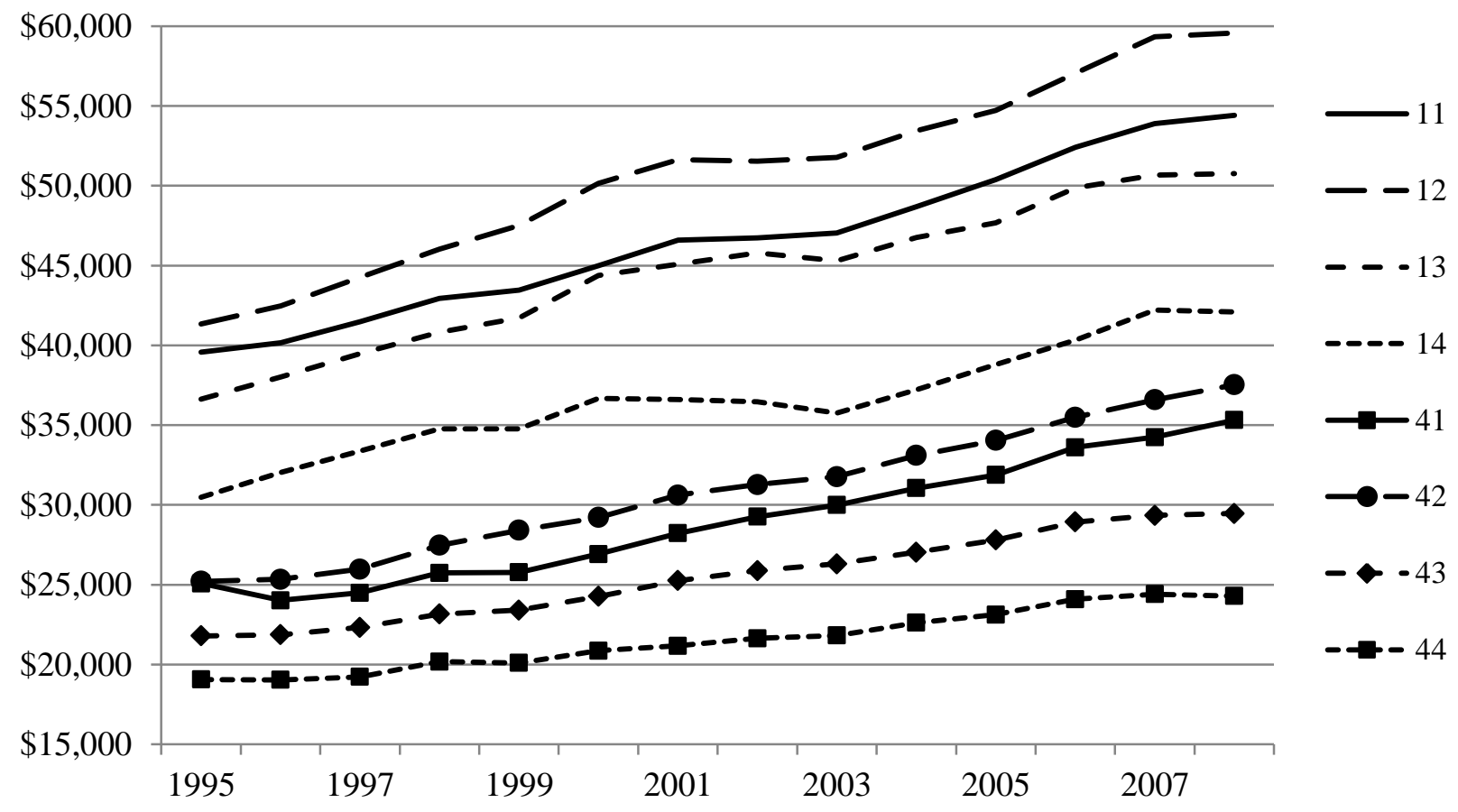

Source: Author's calculations from the LEHD Employment History File. All values have been adjusted for inflation to reflect year 2000 dollars. Only those immigrants who were at least 18 when they first arrived in the U.S. are reported. Trend lines show annual earnings for 8 types of immigrants by quartile of residential own-exposure (only the 1st and 4th) and workplace own-exposure quartile. The first number designates the quartile of residence own-exposure while the second is the workplace own-exposure quartile. 